\title{
Üç Boyutlu Vatandaşlık Performansı Modelinin Türkiye'de Yapı Geçerliği ve Öncülleri
}

\author{
Savaş Ceylan \\ Hacettepe Üniversitesi
}

\author{
Canan Ergin \\ Özyeğin Üniversitesi
}

\begin{abstract}
Özet
Bu çalışmada kişilerarası destek, örgüte destek ve öz-disiplinli inisiyatif boyutlarını içeren vatandaşlık performansı modelinin yapı geçerliğini ve öncüllerini Türkiye'deki çalışan örneklemlerinde incelemek amacıyla üç araştırma gerçekleştirilmiştir. İlk çalışmada vatandaşlık performansının görünüş ve kapsam geçerliği yarı-yapılandırılmış görüşme yöntemi ile incelenmiştir. İkinci çalışmada vatandaşlık performansının faktör yapısı, ayırt edici geçerliği ve güvenirliği 213 katılımcıdan elde edilen verilerle incelenmiştir. Üçüncü çalışmada 613 katılımcıdan toplanan verilerle kişilik değişkenleri, işle bütünleşme, iş doyumu, grup sargınlığı, örgütsel adalet ve örgütsel bağlllık değişkenleri ile vatandaşlık performansı arasındaki ilişki hedef benzerliği yaklaşımı ile incelenmiştir. Bu araştırmanın bulguları, üç boyutlu vatandaşlık performansı yapısının ve ölçeğinin geçerlik ve güvenirliğine ilişkin psikometrik destek olduğunu göstermiştir. Elde edilen bulguların kuramsal ve uygulamaya yönelik doğurguları tartışılmıştır.
\end{abstract}

Anahtar kelimeler: Vatandaşlık performansı, bağlamsal performans, örgütsel vatandaşlık davranışları, yapı geçerliği, hedef benzerliği yaklaşımı

\begin{abstract}
The current study examined the construct validity and predictors of the three-dimensional citizenship performance construct in employed samples in Turkey. Three independent studies were conducted. First, the face and content validity of the citizenship performance construct was examined in a sample of ten participants via semi-structured interviews. Second, the factor structure, discriminant validity, and internal consistency of citizenship performance were examined in a sample of 213 employees. Third, utilizing the target similarity model, the relationships of citizenship performance with personality variables, job involvement, job satisfaction, group cohesiveness, organizational justice, and organizational commitment were tested in a sample of 613 participants. Results provided psychometric support for the three-dimensional citizenship performance conceptualization and scale in the Turkish context. Theoretical and practical implications of the findings are discussed.
\end{abstract}

Keywords: Citizenship performance, contextual performance, organizational citizenship behaviors, construct validity, target similarity model

Yazar Notu: Bu makale, birinci yazarın doktora tez çalışmasına dayanmaktadır.

Yazışma Adresi: Dr. Savaş Ceylan, Hacettepe Üniversitesi Psikoloji Bölümü, 06800, Beytepe / Ankara.

E-posta: savasc@hacettepe.edu.tr

Gönderim Tarihi: 10.09.2018

Kabul Tarihi: 02.05 .2019 
İş ve örgüt psikolojisinin en temel araştırma alanlarından bir tanesi iş performansıdır. İş performansı araştırmalarının ilk yıllarında, görev performansı olarak adlandırılan ve ağırlıklı olarak çalışanın iş tanımında yer alan temel aktivitelere odaklanılmıştır (Viswesvaran ve Ones, 2000). Ancak çok boyutlu bir kavram olan iş performansının, görev performansının ötesinde birçok davranışı kapsadığı bilinmektedir. Resmi iş tanımlarında açıkça belirtilmeyen ama çalışanlara ve örgütlerine yararlı olan bu davranışlar birçok farklı kavram ile tanımlanmıștır. Bunlar arasında örgütsel vatandaşlık davranışları (ÖVD; Bateman ve Organ, 1983; Organ, 1977), asker etkililiği (Borman, Motowidlo, Rose ve Hanser, 1983), olumlu sosyal örgütsel davranışlar (Brief ve Motowidlo, 1986), örgütsel spontanlık (George ve Brief, 1992) ve bağlamsal performans (Borman ve Motowidlo, 1993) sayılabilir. Bu kavramlar arasında en çok ilgi görenler ÖVD (Bateman ve Organ, 1983; Organ, 1977) ve bağlamsal performanstır (Borman ve Motowidlo, 1993). 2019 y1lı itibariyle, Web of Science (WOS) tarama motorunda konusu örgütsel vatandaşlık veya benzeri performans çeşitleri olan indeksli yayınların sayısının 6000'den fazla olduğu görülmektedir. Çalışanların kendileri ve çalıştıkları örgütleri için faydalı olan bu davranışları daha iyi anlamak için bu davranışların 200'den fazla değişkenle ilişkisi incelenmiştir (LePine, Erez ve Johnson, 2002). ÖVD veya bağlamsal performansın öncülleri ve sonuçları, aynı zamanda birçok meta-analize konu olmuştur (örn., Bing, Davison, Minor, Novicevic ve Frink, 2011; Borman, Penner, Allen ve Motowidlo, 2001; Dalal, 2005; LePine ve ark., 2002; Miao, Humphrey ve Quian, 2017, 2018; Podsakoff, Whiting, Podsakoff ve Blume, 2009).

Ancak önemli derecede bilgi birikimi yaratan bu alanyazın, birçok kuramsal ve yöntemsel tartışmaları da içermektedir. $\mathrm{Bu}$ tartışma konularından bir tanesi, kavramsal düzeyde farklı ama davranışsal düzeyde benzer olan yapılar arasındaki örtüşmedir (Bolino, Turnley ve Niehoff, 2004; Motowidlo, 2000). Örgütsel psikoloji alanında sıklıkla karşımıza çıkan kavram kirliliği sorunu, ÖVD ve bağlamsal performans için de geçerlidir (örn., Shaffer, DeGeest ve Li, 2016; Tay ve Drasgow, 2012). Tanımları ve çıkış noktaları farklı olan bu kavramlar, davranışsal düzeyde birbirine çok benzemektedir (Motowidlo, 2000) ve farklı kavram isimleri ile yapılan araştırmalar, elde edilen bilgileri bütüncül bir şekilde takip etmeyi zorlaştırmaktadır (Le, Schmidt, Harter ve Lauver, 2010).

Alanyazında yer alan ikinci önemli tartışma konusu ise ÖVD ve bağlamsal performansın boyutsallığı ile ilişkilidir. ÖVD kavramını tek bir gizil değişken olarak ele alan çalışmalara (örn., LePine ve ark., 2002) ek olarak, iki boyutlu (örn., Smith, Organ ve Near, 1983) veya beş alt boyutlu bir kavram (Organ, 1988) olarak ele alan araştırmalar da vardır. Benzer bir şekilde bağlamsal performansı da tek boyutlu (örn., Motowidlo ve Van Scotter, 1994) veya iki boyutlu bir kavram (örn., Van Scotter ve Motowidlo, 1996) olarak ele alan çalışmalar karşımıza çıkmaktadır. Çok boyutlu kavramların yapı geçerliğini inceleyebilmek için araştırmacıların ilk olarak kavram ile boyutları arasındaki ilişkiyi tanımlamaları gerekmektedir (MacKenzie, Podsakoff ve Podsakoff, 2011). Bir başka deyişle, kavramın alt boyutlarının ortak ve birbirinden farklı olan özellikleri belirlenmelidir. Çok boyutlu kavram çeşitlerini tanımlayan Law, Wong ve Mobley (1998), ÖVD'nin hangi kategoride yer alması gerektiğinin yeterince açık olmadığını belirtmiştir. Bu sonuç, ÖVD, bağlamsal performans ve diğer akraba kavramlar arasındaki örtüşme ile birlikte düşünüldüğünde doğal gözükmektedir.

Özellikle ÖVD ile bağlamsal performans arasındaki benzerliğe odaklanan Organ (1997), vatandaşlık performansı (VP) kavramını ortaya atmıştır. VP, "belirli bir zaman dilimi içinde çalıșanın, ișin psikolojik, sosyal ve örgütsel bağlamına yaptığı toplam katkı" olarak tanımlanabilir (Motowidlo, 2003, s. 39). Coleman ve Borman (2000) ise, VP'yi oluşturan tüm davranışları alanyazından derlemiş ve benzerlik matrisi kullanarak yaptıkları analiz ile üç alt boyut tanımlamışlardır. Kișilerarası destek, örgüte destek ve öz-disiplinli inisiyatif boyutlarını içeren VP kavramı, ÖVD ile bağlamsal performans ekollerini birleştiren sade ve kapsayıcı bir model olması ve kuramsal tartışmalara yanıt olacak şekilde tasarlanması gibi özellikleri dolayısıyla alanyazına önemli bir katk1 sağlamıştır (Borman, Buck ve ark., 2001).

Türkiye'de yapılan çalışmalara göz atıldığında, bazı temel ÖVD (örn., Basım ve Şeşen, 2006; Göncü, Aycan ve Johnson, 2014) ve bağlamsal performans ölçme araçlarının (örn., Bağc1, 2014; Karakurum, 2005) Türkçe'ye adapte edildiği ve araştırmalarda kullanıldığ 1 görülmektedir. Ancak, üç boyutlu VP kavramsallaştırmasını içeren bir araştırmaya ve ölçme aracına rastlanmamıştır. Bu çerçevede, makalenin temel amacı, ÖVD ile bağlamsal performans ekollerini birleştiren VP kavramsallaştırmasının yapı geçerliği ve güvenirliğini Türkiye'de test etmektir. Bu amaç doğrultusunda üç araştırma tasarlanmıştır. İlk çalışmada VP modelinin (Coleman ve Borman, 2000) Türkiye'de görünüş ve kapsam geçerliği incelenmiştir. Böylece, VP kavramsallaştırmasının uluslararası yazınla uyumlu olup olmadığı ve ölçme aracının içeriğine ilişkin ilk değerlendirme yapılmıştır. İkinci çalışmada ölçme aracının yapı ve ayırt edici geçerlik ile güvenirlik incelemesi yapılmıştır. Son çalışmada ise bir, iki ve üç boyutlu VP modelleri karşılaştırılmış ve VP'nin sosyal mübadele kuramı (Blau, 1964; Thibaut ve Kelley, 1959), hedef benzerliği modeli (Lavelle, Rupp ve Bro- 
ckner, 2007), içsel güdülenme (Ryan ve Deci, 2000) ve kişilik alanyazınlarından yararlanılarak seçilen öncülleri incelenmiştir. Böylece hem ulusal hem de kültürlerarası benzerlik ve farklılıklara odaklanan uluslararası alanyazına katkı sağlanması amaçlanmıştır.

Makalede ilk olarak VP kavramını oluşturan ilgili alanyazın özetlenmiş, daha sonra gerçekleştirilen üç çalışmanın amaçları ve bulguları sırasıyla sunulmuştur.

\section{Vatandaşlık Performansı}

Bolino ve arkadaşlarına (2004) göre, VP kavramının içerdiği ÖVD ve benzeri yapılar, alanyazında çok ilgi görmesine rağmen tanımı, boyutsallığ 1 ve içerik benzerliği konusunda yeterince eleştirilmemiştir. Araştırmac1lar, aynı şemsiye kavram içerisinde yer alan 30'dan fazla alt boyut tanımlamışlardır (Coleman ve Borman, 2000; Podsakoff, MazKenzie, Paine ve Bachrach, 2000). Daha açık bir şekilde ifade etmek gerekirse, ÖVD (Smith ve ark., 1983) ve onunla akraba olan kavramlar arasındaki benzerlikler kavram kirliliği yaratmıştır. Organ (1997) tarafından VP olarak yeniden adlandırılan bu araştırma ekolü büyük oranda ÖVD ve bağlamsal performans araştırmalarından beslenmektedir. ÖVD, Organ (1988, s.4) tarafindan "çalışanların isteklerine bağlı olarak yaptıkları, resmi ödül sistemi tarafından doğrudan veya dolaylı olarak tanınmayan ve toplamda örgütün etkililiğine katkıda bulunan bireysel davranışlar" olarak tanımlanmıştır. ÖVD'nin en çok ilgi gören sınıflamalarından bir tanesi elseverlik, lütufkârlık, sportmenlik, vatandaşlık bilinci ve öz-disiplin boyutlarını kapsamaktadır (Organ, 1988). Ancak birçok araştırmada beşli faktör yapısının desteklenmediği ve özellikle son üç boyutunun birbirinden ayrılmadığ1 görülmüştür (örn., Podsakoff, MacKenzie, Moorman ve Fetter, 1990). Benzer bir şekilde, Özen-İ̧şbaşı (2000) tarafından yapılan çalışmada dört boyutlu bir yapı elde edilmiştir. Bu sınıflamaya ek olarak, Williams ve Anderson'ın (1991) modeli de yazında çok ilgi görmüştür (Podsakoff ve ark., 2009). Williams ve Anderson'ın (1991) geliştirdikleri model diğer çalışanların faydasına olan vatandaşlık davranışları (ÖVD-D) ve örgüte faydası olan vatandaşlık davranışları (ÖVD-Ö) ayrımına dayanmaktadır.

ÖVD araştırmalarının çıkış noktası, iş tutumlarının performansın hangi yönlerine olumlu etki yaptığını incelemeye dayanmaktadır (Organ, 1977). Buna karşın, bağlamsal performans araştırmaları, iş performansı ve personel seçme arasındaki ilişkiye odaklanılması sonucu ortaya çıkmıştır. Borman ve Motowidlo’ya (1993) göre ortamsal performans örgütsel, sosyal ve psikolojik iş ortamını olumlu bir biçimde şekillendirmektedir. Borman ve Motowidlo (1993) tarafindan ortamsal performansin beş alt boyutu tanımlanmıștır. Bunlar görevlerini başarılı bir şekilde yapmak için büyük bir heves ve fazladan bir çaba ile çalışmak; resmi olarak kendi işinin bir parças1 olmayan görev aktiviteleri için gönüllü olmak; diğer çalışanlarla iş birliği yapmak ve onlara yardım etmek; örgütsel kural ve işlemlere uymak ve örgütün amaçlarını onaylamak, desteklemek ve savunmaktır. Organ'a (1997) göre bu beş davranış ile ÖVD’nin elseverlik, lütufkârlık, sportmenlik, vatandaşlık bilinci ve öz-disiplin boyutları örtüşmektedir.

Bağlamsal performansın bir diğer sınıflaması ise kişilerarası yardımlaşma ve işe adanma boyutlarını içermektedir (Van Scotter ve Motowidlo, 1996). Kişilerarası yardımlaşma örgütün hedeflerine ulaşmasını kolaylaştıran ve diğer çalışanlara yönelik olarak yapılan davranışları içermektedir. İşe adanma ise kurallara uyma, çok çalışma ve işyerinde ortaya çıkan sorunlarda inisiyatif almayı içermektedir (Van Scotter ve Motowidlo, 1996). Bu ikili sınıflamanın da Williams ve Anderson'ın (1991) ÖVD-D ve ÖVD-Ö yapılarına benzediği görülmektedir (Coleman ve Borman, 2000).

Coleman ve Borman (2000), yukarıda özetlenen iki araştırma kolu ve benzer diğer yapılardan elde edilen bilgileri birleştirebilmek için ilk olarak alanyazında aynı kavramı ölçen 27 farklı davranışı saptamışlardır. Daha sonra, Endüstri ve Örgüt Psikolojisi Birliği (Society for Industrial and Organizational Psychology, SIOP) üyesi uzman yargıcıların yaptıkları değerlendirmelerden bir benzerlik matrisi elde etmiştir. Bu veri kullanılarak yapılan analizler sonrasında üç boyutlu bir vatandaşlık performansı modeli ortaya çıkarmışlardır. $\mathrm{Bu}$ model, gerçek iş performans vakaları kullanılarak test edilmiş ve modelin görgül olarak desteklendiği gösterilmiştir (Borman, Buck ve ark., 2001). Modelde yer alan ilk boyut olan kişisel destek, örgütteki diğer çalışanlara yönelik yapılan davranışları; örgütsel destek örgüte faydalı olacak vatandaşlık davranışlarını içermektedir. Üçüncü boyut olan öz-disiplinli inisiyatif ise çalışanların kendi işlerini daha iyi yapabilmek için gösterdikleri davranışları içermektedir (Borman, Buck ve ark., 2001).

Hem kapsayicı hem de sade olan bu model, Williams ve Anderson'ın (1991) ÖVD-D ve ÖVD-Ö boyutlarını içermektedir. Üçlü modelin en özgün sayılabilecek kısmı bu ikili sınıflamaya öz-disiplinli inisiyatifin eklenmesidir. Coleman ve Borman'a (2000) göre, bağlamsal performans içinde yer alan işe adanma boyutu ise örgütsel destek ve öz-disiplinli inisiyatifin toplamını içermektedir. Dolasıyla, üçlü VP modeli, Williams ve Anderson'ın (1991) sinıflamasına öz-disiplinli inisiyatif boyutunu eklemekte; bağlamsal performans altında yer alan işe adama boyutunu ise örgütsel destek ve öz-disiplinli inisiyatif olarak ikiye bölmektedir. Öz-disiplinli inisiyatif, fazladan çaba gösterme (Borman ve Motowidlo, 1993) ile beklentilerin üzerinde performans gösterme (Van Dyne, Graham ve Dienesch, 1994) gibi göstergeleri 
içermektedir (Coleman ve Borman, 2000). Çalışma hayatındaki en önemli alanlardan birisi olan işin kendisi, bu model ile vatandaşlık performansı şemsiye kavramı içinde yer almaktadır. Örneğin, iş doyumu ölçekleri incelendiğinde, işi yapmaktan duyulan doyum (örn., işin doğası), örgütte yer alan diğer kişilerle (örn., çalışma arkadaşları ve yöneticiler) beraber çalışmaktan duyulan doyum ve örgütün genel olarak işleyişinden duyulan doyum (örn., ödül sistemleri, örgütsel iletişim kanalları) gibi üçlü bir sınıflamanın karşımıza çıktığ1 görülmektedir. Benzer bir şekilde Rupp ve Cropanzano (2002), adalet konusunda, çalışanların yöneticileri ile örgütlerini birbirinden ayırarak bir değerlendirme yaptıklarını belirtmiştir. Dolayısıyla, birçok örgütsel davranış veya tutumu incelerken karşımıza çıkan hedefe yönelik bu ayrım vatandaşlık davranışları araştırmalarında kuramsal bir çerçeve içinde yer bulmaktadır.

Üçlü vatandaşlık performansı modeli ile yapılan çalışmalarda, bu modelin daha işlevsel olduğuna ilişkin bazı kanıtlar sunulmuştur. Borman, Buck ve arkadaşlar1 (2001), 5000 iş performansı örneğini üçlü VP modeli çerçevesinde sınıflamıştır. Schneider, Goff, Anderson ve Borman (2003) tarafından yapılan çalışmada, Borman, Buck ve arkadaşlarının (2001) çalışması genişletilerek tekrarlanmış ve üç boyutlu VP'nin bilgisayar destekli değerlendirme ölçekleri ile ölçülebildiği gösterilmiştir. Borman, Penner ve ark. (2001), kişilik ile iş performansı arasındaki çalışmaları derleyerek bir inceleme yapmıştır. $\mathrm{Bu}$ inceleme sonucunda, üç boyutlu VP kullanıldığında, kişilik ile vatandaşlık performansı arasındaki ilişkinin kuvvetlendiğine ilişkin bulgular rapor etmiştir. Araştırmacılar bu sonucun sebeplerinden biri olarak vatandaşlık performansının daha belirgin alt boyutlarının kullanılmasını göstermişlerdir. Kamdar ve Van Dyne'ın (2007) çalışmasında ise lider-üye mübadelesinin yöneticilere yönelik vatandaşlığ 1 , takım-üye mübadelesinin ise vatandaşlık performansının kişilerarası boyutunu yordadığı rapor edilmiştir. Yukarıda özetlenen çalışmalar, üç boyutlu VP'nin görgül olarak ölçülebildiğinin ve farklı alt boyutların farklı öncüllere sahip olabileceğinin ilk kanıtlarını sunmaktadır.

Vatandaşlık performansı kavramını Türkiye'de ele almaya çalıştığımız bu araştırma sürecinde çalışmalar tasarlanırken alanyazında ölçme aracı (örn., MacKenzie ve ark., 2011) ve kuram test etme (örn., Shaffer ve ark., 2016) ile ilgili tavsiyelerden yararlanılmıştır. Bu bilgilerden hareketle, ilk olarak bu yapıyı ölçmek için seçilen aracın görünüş ve kapsam geçerliğini değerlendirmek üzere bir çalışma gerçekleştirilmiştir. İkinci çalışmada seçilen ölçme aracının temel psikometrik değerlendirilmesi yapılmış ve üçüncü çalışmada ise oluşturulan araştırma modeli, çeşitli alternatif modellerle karşılaştırılarak test edilmiştir.

\section{Çalışma 1 - Vatandaşıık Performansı Ölçeğinin Türkiye'de Görünüş ve Kapsam Geçerliği}

Farh, Zhong ve Organ (2004) tarafindan yapılan çalışmada Çin Halk Cumhuriyet'inden katılımcılardan ÖVD vakaları toplanmış ve batı alanyazınında yer almayan kültürel ÖVD'ler olabileceği sonucu elde edilmiştir. $\mathrm{Bu}$ bilgiden hareketle, birinci çalışma vatandaşlık performansının (Borman, Buck ve ark., 2001; Coleman ve Borman, 2000) Türkiye'ye özgü göstergeleri olup olmadığını incelemek amacıyla tasarlanmıştır. Aynı zamanda görünüş ve kapsam geçerliğinin kanıtlarını araştırmak için tasarlanan bu çalışmada, araştırmanın amaçlarına uygun olarak niteliksel veri toplama teknikleri kullanılmıştır.

Araştırmaya başlamadan önce vatandaşlik performansı ölçeği (Borman, Buck ve ark., 2001), yazarlardan farklı üçer iş ve örgüt psikolojisi profesyoneli tarafından Türkçeye çevrilmiştir. Yapılan çeviriler, farklı üç kişi tarafindan kontrol edilmiş ve anlam bütünlüğünü koruyacak şekilde maddelerin son haline karar verilmiştir.

\section{Katılımcilar}

Toplam on katılımc1 ile derinlemesine yar1-yap1landırılmış görüşme gerçekleştirilmiştir. Katılımcılar kolayda örneklemi ile ve farklı sektörlerden olacak şekilde seçilmiştir. Katılımcıların üçü kamu, yedisi özel sektöre ait işyerlerinde görev yapmaktadır. Katılımcıların üçü kadın ve yedisi erkektir. Katılımcıların toplam çalışma süresi 1 yıl ile 35 yıl arasında değişmektedir ve ortalama süre 11 yıldır. Katılımcıların biri lise, sekizi lisans ve biri lisansüstü derecesine sahiptir.

\section{İşlem ve Görüşme Soruları}

Görüşmeler üç temel bölümden oluşmuştur. İlk aşamada katılımcılara Borman, Buck ve arkadaşları (2001) tarafından yapılmış görev ve vatandaşlık performansı tanımları okunmuş ve bu tanımlardan sonra akıllarına gelen örnek olayları anlatmaları istenmiştir. Kat1lımc1lara verilen görev performansı tanımı "örgütsel mal ve hizmetlerin belirli bir zaman dilimi içinde bir birey tarafindan üretilmesinde bireyin yaptığ tandaşlık performansı tanımı ise "kişinin işin psikolojik, sosyal ve örgütsel bağlamına yaptığı toplam katkı"dır. Yöneltilen bu sorunun amac1, vatandaşlik performansı tanımı ile anlatılan örnek olayların uyuşma durumunu, yani görünüş geçerliğini incelemektir.

İkinci aşamada katılımcılara 15 maddelik VP ölçeğindeki maddeler tek tek okunmuş ve bu maddelerle ilgili başlarından geçen veya gözlemledikleri örnek olayları anlatmaları istenmiştir. Üçüncü aşamada okunan 15 maddenin daha önce kendilerine tanımı yapılan vatandaşlık performansı ölçeği olduğu söylenmiş ve katılım- 
c1ların bu maddeleri tanımla uygun bulup bulmadikları sorulmuştur. Son olarak, katılımcılara, verilen tanıma göre 15 maddeye yeni eklemeler yapmayı önerip önermedikleri sorulmuştur. Böylece ölçeğin kapsam geçerliğine ilişkin bir değerlendirme yapılmıştır. Görüşmeler 55 ile 90 dakika arasında sürmüştür.

Katılımcıların verdikleri bilgiler, iş ve örgüt psikolojisi alanında uzman üç yargıcı tarafından kodlanmış ve yapılan kodlamalar uyuşma oranlarını incelemek için analiz edilmiştir.

\section{Bulgular ve Tartışma}

Yargıcıların yaptıkları değerlendirmeler sonucunda, katılımcıların tamamının vatandaşlık performansı ile ilgili uygun örnekler verdikleri belirlenmiştir. Vatandaşlık performansı ölçeği maddelerine örnek verilmesi istendiğinde katılımcıların büyük bir çoğunluğunun (\%96) uygun örnekler anlattıkları görülmüştür. Son olarak, katılımcıların tamamı, tanım ile maddelerin uygun olduğunu rapor etmiş ve herhangi bir madde önerisi getirmemiştir.

Yukarıda bulguları kısaca özetlenen birinci çalışma, vatandaşlık performansı ölçeğinin adaptasyonu öncesinde kültürel uygunluğun (Güngör, 2016) göstergelerini değerlendirmek için tasarlanmıştır. Bu çerçevede, çalışma bulguları vatandaşlık performansının katılımcılarımız tarafından anlaşıldığını, maddelerinin açık olduğunu ve kapsam geçerliğine ait kanıtlar bulunduğunu göstermiştir. İlk 10 katılımcıdan gelen bilgiler birbirleri ile uyumlu olduğu için daha fazla görüşme yapılmamıştır.

\section{Çalışma 2 - Vatandaşlık Performansının Ayırt Edici Geçerlik ve Güvenirlik Çalışması}

İkinci çalışma, VP ölçeğinin faktör yapısının ilk incelemesini gerçekleştirmek, ölçeğin ayırt edici geçerlik bilgilerini araştırmak ve ölçeğin güvenirliğini test etmek için tasarlanmıştır. Ayrıca, üçüncü çalışmada da kullanılacak olan grup sargınlığı ve işle bütünleşme ölçeklerinin de ön geçerlik ve güvenirlik bilgileri bu aşamada sınanmıştır.

Vatandaşlık performansı ölçeğinin ölçme performansını değerlendirebilmek için ölçekle pozitif ilişki göstermesi beklenen, negatif ilişki göstermesi beklenen ve ilişkili olmaması beklenen değişkenler taranmıştır. VP ile yukarıda bahsedilen ilişkileri gösterebilecek değişken sayısı çok fazladır. Bu çalışmada hem iş hayatı hem de iş dışı hayat ile ilişkili ve Türkçeye adaptasyonu yapılmış farklı kavramlar seçilmeye çalışılmıştır. Böylece yapı geçerliğinin de kanıtları araştırılmıştır (DeVillis, 2016). Bu çerçevede, önceki ÖVD alanyazınından yararlanılarak, VP ile pozitif ilişki göstermesi beklenen de- ğişkenler olarak iş doyumu (örn., LePine ve ark., 2002), grup sargınlığ1 (örn., Kidwell, Mossholder ve Bennett, 1997), işle bütünleşme (örn., Diefendorff, Brown, Kamin ve Lord, 2002) ve iş-aile çatışması (Bolino ve Turnley, 2005) seçilmiştir. İş doyumu hisseden, iş grupları ile olumlu bir iş birliği içinde olan ve işine gömülme eğilimi olan çalışanların daha fazla VP gösterdiği bilinmektedir. Buna ek olarak, VP'yi yüksek düzeyde gösteren çalışanların, bu davranışları ile aile hayatlarından ödün vermeleri arasında pozitif bir ilişki alanyazında yer almaktadır (Bolino ve Turnley, 2005).

VP ile negatif ilişki gösterdiği bilinen değişken olarak ise işten ayrılma niyeti (örn., Podsakoff ve ark., 2009) çalışmaya dahil edilmiştir. Vatandaşlık performans1 ile ilişkisiz çıkması beklenen değişken olarak aile-iş çatışması eklenmiştir. Aile-iş çatışmasının belirleyicileri olarak iş hayatı dışındaki değişkenler daha etkilidir. Bu değişkenlere ek olarak, aşağıda ayrıntıları verilen işin merkeziliği ölçümü çalışmaya eklenmiştir. Çalışma kavramını önemseyen kişilerin daha yüksek derecede VP göstereceği ve boş zaman kavramını önemseyen kişilerin ise bu davranışları daha düşük derecede göstereceği beklenmiştir. Bu iki kavrama ek olarak işin merkeziliği ölçümü içinde yer alan toplum, din ve aile başlıkları için ise vatandaşlık performansı ile anlamlı düzeyde bir ilişki çıkmaması beklenmiştir.

\section{Katılımcular ve İşlem}

Araştırmanın bu aşamasına dört farklı ilden 104'ü kadın (\%48.8), 107'si erkek (\%52.2) toplam 213 kişi katılmıştır. Katılımcıların 132'si kamu (\%62), 77'si (\%38) özel sektöre ait işyerlerinde tam zamanlı çalışmaktadır. Katılımcıların ikisi cinsiyetini, dördü çalıştığ 1 kurumu belirtmemiştir. Katılımcıların yaş ortalaması 33.32 yıl (S $=6.90$, Ranj $=22-61$ ), ortalama çalışma süresi 10.40 yıldır $(\mathrm{S}=7.15$, Ranj $=1-37$ yil $)$ ve katılımcıların $\% 52$ 'si üniversite mezunudur.

Araştırma için gerekli izinler alındıktan sonra ölçekler karışık bir sırada ve zarflar içinde katılımcılara sunulmuştur. Kartopu tekniği ile ulaşılan katılımcılar ölçekleri bireysel olarak doldurmuş ve araştırmacıya iletmiştir.

\section{Veri Toplama Araçlart}

$\mathrm{Bu}$ çalışmada kullanılmış olan işle bütünleşme ve grup sargınlığı ölçekleri yazarlardan farklı iş ve örgüt psikolojisi uzmanları tarafından Türkçeye çevirilmiş, farklı uzmanlar tarafından kontrol edilmiş ve anlam bütünlüğüne önem verecek şekilde maddelerin son haline karar verilmiştir. Vatandaşlık performansı ölçeğinde beş basamaklı Likert tipi sıklık skalası (1 = Hiçbir Zaman, 5 = Çoğu Zaman), diğer tüm ölçeklerde ise beş basamaklı onay skalası ( 1 = Hiç Katılmıyorum, 5 = Kesinlikle Katılıyorum) kullanılmıştır. 
Vatandaşlık Performansı Ölçeği. Borman, Buck ve arkadaşları (2001) tarafindan yapılan üçlü sinıflama çerçevesinde oluşturulan ve birinci çalışmada görünüş ve kapsam geçerliği test edilen 15 maddelik ölçek kullanılmıştır. Ölçek içinde yer alan kişilerarası destek yedi, örgüte destek ile öz-disiplinli inisiyatif boyutları ise dörder madde ile ölçülmüştür. Ölçek maddeleri Ek’te sunulmuştur.

İs Doyиmu. Spector (1997) tarafından oluşturulan 36 maddelik ölçek, ücret, terfi, yönetim, ek faydalar, ödüller, çalışma koşulları, çalışma arkadaşları, işin doğası ve iletişim alt boyutlarından dörder madde içermektedir. Yelboğa (2009) tarafindan Türkçeye uyarlanan ölçeğin güvenirlik katsayıları .63 ile .88 arasında değişmektedir.

Spector'in (1997) iṣ doyumu ölçeğine ek olarak, araştırmada katılımcılara "Genel olarak işinizden ne kadar memnunsunuz?" sorusu sorulmuştur.

Isşle Bütünleşme Ölçeği. Kanungo (1982) tarafından oluşturulan ölçekte tek bir boyutu ölçen 10 madde yer almaktadır. Kanungo (1982) tarafindan rapor edilen güvenirlik ve test-tekrar test katsayıları ise sirasıyla .87 ve .85 'dir. "Çoğu zaman işime gömülmekten hoşlantyorum" ve "Bana göre işim 'kim olduğumun' küu̧ük bir parçasıdır" ölçekte bulunan olumlu ve olumsuz ifadeli maddelere örnektir.

Grup Sargınlı̆̆ı Öllçeği. Çalışanların grup sargınl1$\breve{g}_{1}$ algısını ölçmek için Dobbins ve Zaccaro (1986) tarafindan oluşturulan ve daha sonra Kidwell ve arkadaşları (1997) tarafından yeniden düzenlenen sekiz maddelik ölçek kullanılmıştır. Kidwell ve arkadaşları (1997) tarafindan rapor edilen içtutarlık katsayısı .89'dur. "Grubumun üyeleri ile birlikte olmak için her gün can atıyorum" ve "Genellikle grubumun diğer üyeleri ile iyi geçinemediğimizi düşünüyorum" ölçekte bulunan olumlu ve olumsuz ifadeli maddelere örnektir.

İş-Aile ve Aile-İS Çatışması Ölçekleri. İş-aile ve aile-iş çatışması ölçekleri, daha önce geliştirilen ölçeklerdeki maddeler üzerinde geliştirme ve geçerlik çalışmas1 yapılarak Netemeyer, Boles ve McMurrian (1996) tarafından oluşturulmuştur. Ölçekler Giray ve Ergin (2006) tarafından Türkçeye uyarlanmıştır ve iç tutarlık katsayıları iş-aile ve aile-iş çatışması ölçekleri için sırasyyla .89 ve .76 olarak rapor edilmiştir. Her iki boyut da beşer madde ile ölçülmektedir.

İşin Merkeziliği Sorusu. İșin merkeziliği ölçümü, İşin Anlamı (MOW, International Research Team, 1987) araştırma grubu tarafından kullanılan ölçümlerden birisidir (Misumi ve Yamori, 1991). Tek sorudan oluşan bu ölçümde katılımcılardan toplam 100 puanı, boş zaman, toplum, iş, din ve aile kavramlarına, bu kavramların kendileri için ne kadar önemli olduğuna göre dağıtmaları istenmektedir. Örneğin, her beş kavramın eşit öneme sahip olduğunu düşünen bir katılımc1 her maddeye 20 'şer puan vermektedir.

İşten Ayrlma Niyeti. Walsh, Ashford ve Hill (1985) tarafindan oluşturulan ölçek sekiz madde içermektedir ve Cronbach Alfa güvenirlik katsayısı .90'dır. Ölçeğin Ok (2007) tarafindan Türkçeye uyarlanan beş maddesi kullanılmıştır. Bu beş maddenin güvenirlik katsay1s1 .76'dir.

Demografik Bilgi Formu. Katılımcılardan yaş, cinsiyet, meslek, kurum (kamu-özel), toplam çalışma süresi, şimdiki işyerinde toplam çalışma süresi ve eğitim düzeyi gibi demografik bilgileri alınmıştır.

\section{Bulgular ve Tartışma}

Yapılacak analizler öncesi veriler tekli ve çoklu bağlantı sayıltıları açısından değerlendirilmiştir ve herhangi bir katılımcının analiz dışı tutulmasına gerek olmadığı sonucuna ulaşılmıştır. Daha sonra araştırmada kullanılan ölçeklerin faktör yapılarının orijinalleri ile uyumlu olup olmadığını değerlendirmek için doğrulayıcı faktör analizi (DFA) yapılmıștır. Lisrel 8.54 (Jöreskog ve Sörbom, 2003) programı kullanılarak yapılan analizlerde kovaryans matrisi kullanılmıştır. DFA sonucunda iş doyumu ölçeğinde yer alan üç, işle bütünleşme ölçeğinde yer alan iki ters kodlanmıș maddenin anlamlı faktör yükü almadığı görülmüș ve bu maddeler takip eden analizlerin dışında tutulmuştur. Diğer tüm maddeler ilgili faktörlerin altında yer almıştır. Araştırmada yer alan ölçeklerin ortalama, standart sapma, iç tutarlık katsayıları ile değişkenler arasındaki korelasyonlar Tablo 1'de gösterilmiştir. Tek maddelik iş doyumu sorusu ve işin anla$\mathrm{m} ı$ ölçümleri ile ilgili bulgular metin içinde verilmiştir.

Araştırmada kullanılan tüm ölçeklerin aynı anda analiz edildiği DFA sonuçlarını değerlendirebilmek için ilk olarak ki-kare testi kullanılmıs ve bu değerin anlamlı olduğu görülmüștür $(\chi 2(146, N=213)=330, p<.001)$. Maccallum, Browne ve Sugawara (1996) tarafindan da belirtildiği gibi ki-kare testi belirli bir sayının üzerindeki örneklemlerde model ile veri uyumlu olsa bile anlaml çıkabilmektedir. Ki-kare değerinin bu özelliği sebebiyle modelin uygunluğunu değerlendirebilmek için ek uyum indeksleri değerlendirmeye alınmıştır.

Tablo 2'den de görülebileceği gibi ki-kare tam uyum testi anlamlı olmasina rağmen model ile veriler arasında yakın uyum açısından anlamlı bir fark yoktur $(p>.50)$. RMSEA değeri olarak .045 elde edilmiştir ve güven aralıkları ranjının .06 'nın altında olduğu görülmektedir (Hu ve Bentler, 1999). ECVI değeri ise genellikle alternatif modellerin karşılaştııılması için kullanılmaktadır ve düşük değerler iyi uyuma işaret etmektedir (Klein, 2005). CFI ve TLI değerlerinin kabul edilebilir olması için .90, iyi uyuma işaret edebilmesi için . 95 'in 
Tablo 1. Çalışma 2'de Kullanılan Ölçeklerin Ortalamaları, Standart Sapmaları, Cronbach Alfa Değerleri ve Değişkenler Aras1 Korelasyonlar

\begin{tabular}{|c|c|c|c|c|c|c|c|c|c|c|c|}
\hline & & 1 & 2 & 3 & 4 & 5 & 6 & 7 & 8 & 9 & 10 \\
\hline 1 & Vatandaşlık Performansı & $.89^{\dagger}$ & & & & & & & & & \\
\hline 2 & Kişilerarası Destek & $.86^{* *}$ & $.80^{\dagger}$ & & & & & & & & \\
\hline 3 & Örgüte Destek & $.80^{* *}$ & $.48 * *$ & $.85^{\dagger}$ & & & & & & & \\
\hline 4 & Öz-disiplinli İnisiyatif & $.86^{* *}$ & $.61 * *$ & $.61 * *$ & $.78^{\dagger}$ & & & & & & \\
\hline 5 & İş Doyumu & $.15^{*}$ & .08 & $.29^{* *}$ & .04 & $.88^{\dagger}$ & & & & & \\
\hline 6 & İşle Bütünleşme & $.28^{* *}$ & $.18 * *$ & $.24 * *$ & $.29 * *$ & $.18^{* *}$ & $.90^{\dagger}$ & & & & \\
\hline 7 & Grup Sargınlığ1 & $.30^{* *}$ & $.28 * *$ & $.26^{* *}$ & $.21 * *$ & $.52 * *$ & $.14^{*}$ & $.87^{\dagger}$ & & & \\
\hline 8 & İşten Ayrılma Niyeti & -.11 & -.05 & $-.20 * *$ & -.05 & $-.39 * *$ & -.04 & $-.35 * *$ & $.90^{\dagger}$ & & \\
\hline 9 & İş-aile Çatışması & $.28^{* *}$ & $.27 * *$ & $.14^{*}$ & $.30^{* *}$ & $-.18 * *$ & $.33 * *$ & -.07 & $.19^{* *}$ & $.90^{\dagger}$ & \\
\hline \multirow[t]{3}{*}{10} & Aile-iş Çatışması & .01 & .05 & -.04 & -.01 & $-.13 *$ & .04 & -.00 & $.15^{*}$ & $.40 * *$ & $.90^{\dagger}$ \\
\hline & Ort. & 3.64 & 3.63 & 3.82 & 3.48 & 2.99 & 2.74 & 3.39 & 1.86 & 3.08 & 2.32 \\
\hline & SS & 0.62 & 0.62 & 0.82 & 0.84 & 0.49 & 0.88 & 0.69 & 0.96 & 0.99 & 0.83 \\
\hline
\end{tabular}

Not. $N=213, * * p \leq .01, * p \leq .05,{ }^{\dagger}$ Cronbach Alfa değerleri

Tablo 2. Çalışma 2 DFA Uyum İndeksleri

\begin{tabular}{lccccccccc}
\hline Model & sd & $\chi^{2}$ & $\begin{array}{c}\mathrm{p} \\
\text { (tam } \\
\text { uyum) }\end{array}$ & $\begin{array}{c}\mathrm{p} \\
\text { (yakın } \\
\text { uyum) }\end{array}$ & RMSEA & $\begin{array}{c}\text { RMSEA } \\
\text { Güven Aralıkları }\end{array}$ & ECVI & CFI & TLI \\
\hline Yokluk Modeli & 171 & $3519.54^{* *}$ & .00 & .00 & - & - & 5.94 & - \\
DFA & 146 & $330.00^{* *}$ & .00 & .90 & .045 & $(.038-.052)$ & 0.68 & .95 & .94 \\
\hline
\end{tabular}

Not. $N=213, * * p<.01$; RMSEA = Yaklaşı hataların ortalama karekökü; ECVI = Beklenen çapraz geçerlik indeksi; CFI = Karşıllaştırmalı uyum indeksi; TLI $=$ Tucker-Lewis indeksi.

üzerinde olması gerekmektedir (Hu ve Bentler, 1999) ve her iki değer de kritik değerin üstündedir. Genel olarak değerlendirmek gerekirse araştırmanın bu aşamasında kullanılan tüm ölçeklerin faktör yapılarının orijinalleri ile uyumlu çıktığ 1 görülmüştür. VP ile alt boyutları arasındaki ilişki yüksek $(r=.80-.86, p<.01)$ ve boyutların kendi aralarındaki korelasyonlar ise orta düzeydedir $(r=$ $.48-.61, p<.01)$. Bu bulgu, üç alt boyutun hem VP ile yüksek ilişki gösterdiğini hem de belirli düzeyde farkl1laştığını işaret etmektedir ve VP ölçeğinin yapı geçerliğinin ilk kanıtı olarak kabul edilebilir.

VP ile pozitif ilişki göstermesi beklenen değişkenlerin (iş doyumu ölçeği, tek soruluk iş doyumu, grup sargınlığ 1 , işle bütünleşme ve iş-aile çatışması) .15 ile .30 arasında değişen korelasyon değerleri aldığı görülmektedir.
İşten ayrılma niyeti ile VP arasındaki ilişki ise negatif olmasına rağmen anlamlı düzeyde değildir. Ancak, örgüte destek boyutu ile işten ayrılma niyeti arasındaki ilişkinin anlamlı düzeyde olduğu görülmektedir ( $r=$ $-.20, p<.01)$.

VP ile aile-iș çatışması arasındaki ilişki, beklendiği gibi anlamlı düzeyde değildir. VP ile işin merkeziliği ölçümleri arasındaki ilişki incelendiğinde, VP ile çalışmaya verilen önem arasında pozitif ve anlamlı $(r=.18$, $p<.05)$ ve boş zamana verilen önem arasında ise negatif ve anlamlı $(r=-.13, p<.05)$ ilişki olduğu görülmektedir. Boş zamana verilen önem ile VP'nin öz-disiplinli inisiyatif boyutu arasındaki ilişki de anlamlı düzeydedir ( $r=$ $-.16, p<.05)$.

Son olarak, Tablo 1'de görüldüğü üzere, VP'nin Cronbach alfa katsayısı .89 olarak bulunmuştur. VP'nin 
üç alt boyutunun güvenirlik katsayıları ise .78 ile .85 arasında değişmektedir. Yukarıda özetlenen bulgulardan hareketle araştırmada kullanılan değişkenlerin yeterli yapı ve ayırt edici geçerlik ile güvenirlik kanıtlarına sahip olduğu kararına varılmış ve üçüncü çalışmaya geçilmiştir.

\section{Çalışma 3 - Vatandaşıı Performansının Yapısı ve Öncülleri}

İlk iki çalışmada geçerlik ve güvenirlik bilgileri özetlenen VP kavramının faktör yapısını ve öncüllerini test etmek için yapılan üçüncü çalışmanın ilk amacı VP'nin çok-boyutlu bir kavram olarak nasıl ele alınmas1 gerektiğini incelemektir. Birçok çok-boyutlu örgütsel kavramın tanımlanmasında ve ölçülmesinde yaygın hatalar yapılmaktadır. Bunların başında incelenen kavram ve alt boyutları arasındaki ilişkinin tanımlanmamış olmas1 gelmektedir (Wong, Law ve Huang, 2008). Çoğu araştırmada belirli bir alt boyut ile ilgili elde edilen bir bulgu, kavramın tamamı için geçerliymiş gibi yorumlanmakta ve yazında hatalı bilgilere yol açmaktadır (Law ve ark., 1998; Law, Wong, Huang ve Li, 2008; LePine ve ark., 2002). Wong ve arkadaşları (2008) tarafindan yapılan çalışmada genel kavram veya alt boyutlar üzerinden analiz yapıldığ 1 zaman, sonuçların farklılaştığ vatandaşlık davranışları örneği ile görgül olarak gösterilmiştir. Wong ve arkadaşları, Bagozzi, Verbeke ve Gavino (2003) tarafından yapılan çalışmayı yeniden analiz etmiştir. Bagozzi ve arkadaşları, satış temsilcilerinin hissettikleri utanç duygusunun, ÖVD ile pozitif ilişkili olacağı denencesini Filipinler ve Hollanda örneklemlerinde test etmiştir. ÖVD’yi dört ayrı alt boyut olarak ele aldıkları çalışma sonrasında Filipinler örnekleminde utanç ile vatandaşlık bilinci arasında anlamlı bir ilişki rapor etmişlerdir. Ancak bu verileri yeniden analiz eden Wong ve arkadaşları, ÖVD'yi dört alt boyutun altında yatan tek bir gizil değişken olarak ele aldıklarında, iki değişken arasındaki anlamlı ilişkinin ortadan kalktığını göstermiştir. Dolayısıyla, Wong ve arkadaşları, bir alt boyut için elde edilen bir bulgunun, kavramın tamamına genellenmesinin sakıncasını ortaya koymuştur.

Çok-boyutlu yapılar Law ve arkadaşları (1998) tarafindan gizil model, toplam model ve profil modeli olarak sınıflanmaktadır. Gizil modelde tüm alt-boyutların altında yatan ortak bir varyans söz konusudur. Toplam modelde ise söz konusu çok boyutlu kavram, tüm alt boyutların bir araya gelmesi ile oluşmaktadır. Son olarak profil modelinde çeşitli alt boyutların yüksek veya düşük değerlere göre sınıflanması ile çeşitli kombinasyonlar oluşmaktadır. Law ve arkadaşları (1998) tarafindan yapılan bu değerlendirme daha sonra bazı kuramcıları harekete geçirmiş ve ÖVD ile bağlamsal performans hakkında bu çerçevede yorumlar yapmalarına sebep olmuştur.
Law ve arkadaşlarının (1998) yaptığı sınıflama çerçevesinde bağlamsal performans kavramını değerlendiren Motowidlo (2000), çalışanın örgütün sosyal ve psikolojik bağlamına yaptığı toplam katkı olarak tanımlanan bağlamsal performansin toplam model çerçevesinde ele alınması gerektiğini belirtmiştir. LePine ve arkadaşları (2002) tarafindan yapılan meta-analizde ise ÖVD'nin beş alt boyutu (öz-disiplin, lütufkârlık, sportmenlik, elseverlik ve vatandaşlık bilinci) alanyazında öne çıkan yordayıcılar ile birlikte ele alınmış ve ÖVD'nin örtük bir değişken olarak ele alınmasının daha doğru olabileceği iddia edilmiştir. Bu görüşün temelinde çeşitli yorday1cılar ile ÖVD boyutları arasındaki ilişkilerin benzer düzeyde olması yatmaktadır. Ancak meta-analiz çalışmalarına dahil edilen çalışmaların çoğunda ÖVD ile tek veya iki değişkenin ilişkisi incelenmektedir. Örneğin, ÖVD ile iş doyumu arasındaki ilişkiyi inceleyen çalışmalardaki etki büyüklüğü, meta-analizde bir araya getirilmekte ve belirli bir değer ortaya çıkmaktadır. Ancak bu değerin salt belirleyicisinin iş doyumu olduğunu söylemek yeterli olmayabilir. İş doyumu ile ÖVD arasındaki ilişkiyi belirleyen üçüncü değişkenlerin etkisi, meta-analitik korelasyon içinde yer almamaktadır. Bu açıdan baktığımızda, LePine ve arkadaşları (2002) tarafından belirtildiği gibi, 200'den fazla değişkenin ÖVD ile özgün ilişkisi olması gerçekçi olmayabilir. Ayrıca LePine ve arkadaşları (2002) tarafından da söylendiği gibi bu yorumun, bu amaç için tasarlanmış görgül araştırmalarla desteklenmesi gerekmektedir. LePine ve arkadaşları (2002), oluşturulacak kuramsal çerçeve ile yapılacak araştırmalara ihtiyaç olduğunu ve farklı ÖVD (ve benzeri sınıflamaların) boyutlarının farklı yordayıcılarının olup olmadığının mutlaka araştırılması gerektiğini belirtmişlerdir. Hoffman, Blair, Meriac ve Woehr (2007) bir anlamda LePine ve arkadaşlarının (2002) iddiasını sınamak için yaptıkları meta-analizde ÖVD ile görev performansı ayırımının yapı geçerliğini incelemiş ve ÖVD’nin görev performansı ile yakından ilişkili olmasına rağmen ondan ayrı tek bir örtük değişken olarak ele alınabileceği sonucunu elde etmişlerdir.

Ancak, bu araştırmada incelenmek üzere seçilen VP modeli, aşağıda kısaca bahsedilen kuramsal çerçeveler 1şı̆̆ında, farklı boyutları içeren bir şemsiye kavram olarak görülmektedir. Dolayısıyla, kişilerarası destek, örgüte destek ve öz-disiplinli inisiyatif kavramlarının farklı öncülleri olacağı denencesi sınanmıştır. Daha açık bir şekilde söylemek gerekirse, gizil değişken modeli (tek bir boyut) ile toplam değişken (birbirinden göreli bağımsız alt boyutlar) modelleri karşılaştırmalı olarak incelenmiştir. Motowidlo (2000) tarafindan belirtildiği gibi, VP için profil modeli söz konusu olamayacağ için bu konuda herhangi bir model oluşturulmamıştır. Bu iki modele ek olarak, alanyazında sıklıkla karşımıza 
çıkan Williams ve Anderson'ın (1991) ikili modeli, üçlü VP'nin alternatifi olarak test edilmiştir. Daha önce belirtildiği gibi, Coleman ve Borman'ın (2000) önerdiği modelin en özgün yönü öz-disiplinli inisiyatif boyutunun eklenmesidir. Böylece, üçlü VP modelinin, Williams ve Anderson'ın (1991) modelin ötesinde bir geçerliği olup olmadığ1 görgül olarak araştırılmıştır.

Yukarıda bahsedilen amaçları tamamlayacak olan bir diğer unsur ise üçlü VP modelinin öncüllerini araştırmaktır. Bu amaçla, hem daha önce ÖVD ve benzeri kavramları içeren bireysel çalışmalar ve meta-analizler (örn., Borman, Penner ve ark., 2001; Dalal, 2005; Hackett, Farh, Song ve Lapierre, 2003; Ilies, Nahrgang ve Morgeson, 2007; Judge, Thoreson, Bono ve Patton, 2001; LePine ve ark., 2002; Organ ve Ryan, 1995; Podsakoff, MacKenzie ve Bommer, 1996; Podsakoff ve ark., 2009) incelenmiş hem de VP boyutları ile ilişkili olabilecek ama alanda çok fazla ilgi görmemiş değişkenler üçlü model çerçevesinde taranmıştır. Bu konudaki değerlendirmeler sonucunda, üçlü VP boyutlarının birbirinden farklı olabilecek öncülleri seçilmiştir. Öncüller ile ilgili denenceler, iki ve üç boyutlu VP modellerine göre ayrı ayrı oluşturulmuştur. $\mathrm{Bu}$ çalışmada elde edilen veriler doğrultusunda VP'nin faktör yapısı incelendikten sonra denenceler uygun modele göre test edilmiştir.

Coleman ve Borman'ın (2000) üçlü VP modelini test etmeyi içeren bu çalışma, aynı zamanda Türkiye örnekleminde bu modeli ve öncüllerini test eden ilk çalışmadır. Öncüllerin seçilmesinde üç farklı kuramsal yaklaşım ağırlık kazanmaktadır. Bunlardan ilki olan sosyal mübadele kuramının (Blau, 1964; Thibaut ve Kelley, 1959) getirdiği açıklamalar kullanılarak ÖVD’nin öncülleri olarak örgütsel bağlılık (örn., Gregersen, 1993; O’Reilly ve Chatman, 1986), güven (örn., Konovsky ve Pugh, 1994; Podsakoff ve ark., 1990), örgütsel adalet (örn., Farh, Podsakoff ve Organ, 1990, Moorman, 1991; Niehoff ve Moorman, 1993), alg1lanan örgütsel destek (örn., Eisenberger, Fasolo ve Davis-LaMastro, 1990), iş doyumu (örn., Bateman ve Organ, 1983; MacKenzie, Podsakoff ve Ahearne, 1998) ve lider-üye mübadelesi (örn., Schnake, Dumler ve Cochran, 1993) gibi kavramlar incelenmiştir. Aşağıda ayrıntıları verilen denencelerin bir kısmı çalışanların örgütlerinden ve beraber çalıştıkları iş arkadaşlarından memnuniyetinin yansıması olarak düşünülebilir.

İkinci olarak ise hedef benzerliği modeli ele alınmıştır. Hedef benzerliği yaklaşımı (Lavelle ve ark., 2007) özellikle tutum değişkeninin yöneltildiği kişi veya alıcıya göre farklılık göstereceğini içeren bir bakış açısıdır. Bu yaklaşımın iki önemli yansıması bulunmaktadır. Bunlardan ilki, bir tutum değişkeninin, örneğin duygusal bağlılık kavramının, örgütün geneline, yöneticilere veya çalışma grubuna farklı düzeylerde gösterilebileceği ger- çeğidir. İkincisi ise, belirli bir tutumun, o tutumla ilişsili olan diğer değişkenleri daha güçlü derecede yordayacak olmasıdır. Bir başka şekilde ifade etmek gerekirse, örgüte yönelik bir tutum, doğrudan örgüte yönelik bir davranışı daha iyi yordayacaktır. $\mathrm{Bu}$ iki yansıma ile birlikte düşünüldüğünde, üçlü VP modelinin kuramsal temeli sağlamlaşmaktadır. Aşağıda yazılan denenceler, bu yaklaşımın da sonucu olarak oluşturulmuştur.

$\mathrm{Bu}$ çalışmanın dayandığı üçüncü kuramsal yaklaşım ise içsel güdülenme yaklaşımıdır (örn., Ryan ve Deci, 2000). Üçlü VP modeli içerisinde yer alan öz-disiplinli inisiyatif boyutu, tanımı gereği herhangi bir açık dışsal ödül olmaksızın çalışanın kendi işini daha iyi yapmasını içermektedir. Bu boyutun yordayıcısı olarak seçilen değişkenler, bu açıdan bakıldığında içsel güdülenme ile ilişki olarak düşünülebilir.

\section{Işs Doyumu ve VP}

İş doyumu "çalışanların işlerinden ve işlerinin belirli yönlerinden duydukları memnuniyet"tir (Spector, 1997, s. 2). Tanımda da vurgulandığı üzere hem genel olarak işin kendisi hem de işin çeşitli alt boyutları iş doyumu veya doyumsuzluğu yaratabilmektedir. İş doyumu ile ÖVD arasındaki ilişki hem uluslararası alanyazında birçok meta-analiz ile (örn., LePine ve ark., 2002) hem de ulusal alanyazında birçok görgül çalışma (örn., Şeşen ve Basım, 2010) ile incelenmiş ve genellikle orta düzeye yakın ilişkiler rapor edilmiştir. Hem sosyal mübadele kuramı hem de hedef benzerliği modeli çerçevesinde düşünülecek olursa iş doyumunun çeşitli alt boyutları farklı iş davranışlarını etkileyecektir. Organ (1994) iş doyumu gibi genel değişkenlerin, belli bazı davranışları değil, genel davranışları daha iyi yordayacağını belirtmiştir. Ilies ve arkadaşları (2007), Organ'ın görüşüne benzer bir şekilde, VP'nin öncülleri incelenirken, yordayıcı ile VP davranışı arasındaki tematik uyumun dikkate alınması gerektiğini söylemiştir.

Bu çerçevede, Coleman ve Borman'ın (2000) üçlü sınıflaması içinde sosyal mübadele kuramı ve hedef benzerliği yaklaşımı içerisinde kişilerarası destek boyutu ile en çok ilişkili olması beklenen iş doyumu boyutu çalışma arkadaşlarından doyumdur. Kişilerarası destek boyutu, daha önce açıklandığı gibi, temelde örgütte yer alan diğer çalışanlara yardım etme ile ilişkili bir boyuttur. Çalışanlar çok ağırlıklı olarak beraber çalıştıkları kişilerle iletişim içinde olduğu için çalışma arkadaşlarından doyum elde eden çalışanların, bunun karşılığ olarak VP'nin kişilerarası destek boyutunda yer alan davranışları sergilemeleri beklenmektedir. İkili sınıflama içinde düşünülecek olursa, çalışma arkadaşlarından doyumun diğer çalışanlara yardım etmeyi içeren boyut olan ÖVD-D ile ilişkili olması beklenmektedir. Dolayısiyla, 
Hipotez 1: Çalışma arkadaşlarından doyum, üçlü VP s1nıflaması içinde Kişilerarası Destek boyutunu; ikili VP sınıflaması içinde ÖVD-D boyutunu yordayacaktır.

Örgütsel destek boyutu ile en yüksek ilişki göstermesi beklenen iş doyumu boyutunun ise yöneticiden sağlanan doyum olacağı söylenebilir. Yöneticiler çoğu durumda çalışanların gözünde örgütü temsil eden kişi olarak görülmektedir. Yöneticisinden memnun olan çalışanların, bu memnuniyetlerini örgütleri için daha fazla çaba harcayarak göstereceği söylenebilir. Örgüte destek boyutu, daha önce açıklandığı gibi örgütü korumak, zorluklara rağmen örgütte çalışmaya devam etmek, örgütün amaçlarını ve hedeflerini desteklemek ile kurallara uymak gibi davranışları içermektedir. Yöneticisinden memnun olan çalışanların bu davranışları daha çok sergileyeceği beklenmektedir. Vatandaşlığın ikili sınıflaması içinde düşünülecek olursa yöneticiden doyumun ÖVD-Ö ile ilişkili olacağı söylenebilir. Dolayısıyla,

Hipotez 2: Yöneticiden doyum, üçlü VP sınıflaması içinde Örgüte Destek boyutunu; ikili VP sınıflaması içinde ÖVD-Ö boyutunu yordayacaktır.

Coleman ve Borman'ın (2000) üçlü sınıflaması içinde düşünüldügüünde Öz-disiplinli İnisiyatif boyutu ile en yüksek ilişki göstermesi beklenen iş doyumu boyutu işin doğasından duyulan doyumdur. Öz-disiplinli inisiyatif boyutu tarafindan kapsanan davranışlar arasında zor koşullara rağmen ekstra çaba göstererek sebat etmek ve inisiyatif alarak bazı işleri üstlenmek gibi davranışlar sayılabilir. Yaptıkları işi, işin doğasından dolayı seven çalışanların bu davranışları göstermesi daha olasıdır. İşindeki aktivitelerden keyif alan ve işini anlamlı bulan bir çalışan, içsel güdülenme süreçleri ile bu davranışları gösterebilir. Çalışanın, işinin doğasından doyum sağlaması, herhangi bir dişsal beklenti olmadan, hoşuna gittiği için ve içsel güdülenme ile işini yapmasına bağlı olabilir. Spector (1997) tarafından belirtildiği gibi, iş doyumunun bu yönü çalışanların yeteneklerini kullanması, başarma duygusunu tatması ve bağımsızlık yaşayabilmesi gibi içsel ödüllerle ilişkilidir. Vatandaşlığın ikili sınıflaması içinde düşünülecek olursa, işin doğasından doyum ÖVD-Ö ile ilişkili olacaktır. Dolayısıyla,

Hipotez 3: İşin doğasından doyum, üçlü VP sınıflaması içinde Öz-disiplinli İnisiyatif boyutunu; ikili VP sınıflaması içinde ÖVD-Ö boyutunu yordayacaktır.

\section{Örgütsel Bağlılık ve VP}

Örgütsel bağl1lık "bireyin belirli bir örgütle özdeşiminin ve bütünleşmesinin göreli gücü” olarak tanımlanmaktadır (Mowday, Steers ve Porter, 1979, s. 226). Meyer ve Allen (1984), örgütsel bağlllıkla ilgili iki boyutlu modellerini ortaya atmış ve bu boyutları duygusal bağlılık ve devamlılık bağlılı̆̆ Çalışanın kurumunu sevdiği için ona bağlılık göster- mesi duygusal, çalışanın örgütten ayrılmanın maliyetini düşünerek bağlılık göstermesi ise devamlılık olarak tanımlanmıştır. Allen ve Meyer (1990) bu bağlılık türlerine normatif bağlılığ1 da üçüncü bir tür olarak eklemiştir. İlk olarak Weiner ve Vardi (1980) tarafindan yazına kazandırılan normatif bağl1lık, bireyin örgütte kalmanın doğru şey olduğuna inanması sebebiyle ortaya koyduğu bağlılık olarak tanımlanabilir. Uluslararası çalışmalarda meta-analitik düzeyde genellikle duygusal ve normatif bağlılığın arasındaki ilişki yüksek bulunmaktadır (Meyer, Stanley, Herscovitch ve Topolnytsky, 2002). Benzer sonuçlar Türkiye'de yapılan bazı araştırmalarda da (örn., Güleryüz, 2010; Güleryüz, Giray ve Ceylan, 2006; Wasti, 2005) karşımıza çıkmaktadır. Bu durumun olası iki açıklamasından ilki bu iki boyutun katılımcılar tarafindan ayırt edilememesi; ikincisi ise normatif bağlılı̆̆ın, yazında belirtilenin aksine, olumlu örgütsel sonuçları elde etme açısından en az duygusal bağlılık kadar önemli bir yordayıcı olmasıdır. İkinci açıklamanın geçerli olduğu varsayımı, Türkiye'nin kültürel özelliklerinin normatif bağlılığı önemli kıldığı sonucuna yol açabilir.

Örgütsel bağlılık düzeyi, hangi VP çeşidinin ne kadar gösterileceğini belirleyen bir etken olabilir (Paine ve Organ, 2000). Örgütsel bağlılık, tanımı gereği, çal1şanın göreli olarak belirli bir örgüt ile özdeşiminin gücü ve örgütle bütünleşmesi olduğu için, belirli bir örgütte çalışmaya devam etmek isteyen, örgütün hedeflerini benimseyen ve örgütün iyiliği için ekstra çaba gösteren çalışanların örgütlerine bağlı olduklarını söyleyebiliriz. Bunun karşılığı olarak da çalışanların örgütlerinden beklentileri olur. $\mathrm{Bu}$ karşılık parasal olabileceği gibi iş güvencesi veya koruma olarak da karşımıza çıkabilir. Bir çalışanın örgütüne bağlılığı çalışanın kişiliği, işin özellikleri ve örgüt yapısının bir etkileşimi olarak karşımıza çıkar (Mowday, Porter ve Steers, 1982). Ancak burada kültürün de etkisinden bahsetmek gerekir. Bu bağlamda, örneğin, Paine ve Organ (2000) tarafindan toplulukçu kültürlerde iç-grup kavramının önemi sebebiyle genel olarak bağlılığın, özelde ise normatif bağlılığın daha yüksek olacağı iddia edilmiştir.

ÖVD ile örgütsel bağlılık arasındaki ilişkiyi inceleyen çalışmalarda tutarlı olarak pozitif ilişkiler rapor edilmiştir (örn., LePine ve ark., 2002; Morrison, 1994; Organ ve Konovsky, 1989; Organ ve Ryan, 1995). Bu konuda yapılan meta-analizlere baktığımız zaman, Organ ve Ryan'ın (1995) örgütsel bağlılık ile genel uyum ve elseverlik boyutları için rapor ettiği değerlerin sırasıyla .32 ve .25 olduğu; LePine ve arkadaşlarının (2002) ise örgütsel bağlılık ile ÖVD boyutları arasındaki ilişkiyi .20 olarak buldukları görülmektedir. Meyer ve arkadaşları (2002) tarafından yapılan meta-analizde ise ÖVD ile duygusal ve normatif bağlılık arasında sırasıyla .32 ve .24 rakamları elde edilmiştir. Bu çalışmanın bir başka il- 
ginç bulgusu her iki rakamın, Kuzey Amerika dışındaki araştırmalarda .46'ya ve .37'ye yükselmesidir. Gürbüz (2006) tarafından yapılan çalışma duygusal bağlılık ile genel ÖVD arasındaki ilişkinin .39 düzeyinde olduğu, alt boyutlarla olan ilişkinin ise .17 (nezaket) ile .51 (sportmenlik) arasında değiştiği rapor edilmiştir.

Örgütsel bağlılık, tanımı gereği, çalışanın örgütle bütünleşmesi ve örgütte çalışmaya devam etmeyi istemesi durumunda ortaya çıkmaktadır. Örgütte kalmak isteyen çalışanlar, doğal olarak örgütün iyiliği için vatandaşlık davranışları gösterecektir. Sosyal mübadele çerçevesinde ele alacak olursak, çalışanlar örgütlerinden olumlu bir şeyler elde ettikleri için örgütlerine bağlı olacak; dolayısıyla bunun karşılığı olarak ÖVD gösterecekler diye düşünülebilir. Çalışan, örgütünü sevdiği için veya bir zorunluluk olarak gördüğü için bağlılık hissedebilir. Altta yatan sebep farklı olmakla beraber, sonucun çalışanı aynı noktada birleştirdiği iddia edilebilir. Uzun vadede, çalışanın hissettiği zorunluluk, bilişsel bir çelişki yaşamamak için duygusal bağlılık benzeri tepkileri ortaya çıkaracaktır diye tahmin edilebilir. Yazında normatif bağlılığın, duygusal bağlılık kontrol edildikten sonra bir takım örgütsel davranışları hem anlamlı düzeyde yordadığına (Lee, Allen, Meyer ve Rhee, 2001; Meyer, Allen ve Smith, 1993) hem de yordayamadığına (örn., Jaros, 1997; Ko, Price ve Mueller, 1997) ilişkin bulgular mevcuttur. $\mathrm{Bu}$ araştırmada duygusal ve normatif bağlılığın bir arada kullanılması durumunda yordamanın anlamlı düzeyde olacağı sayıltısı ile hareket edilmiştir. Ayrıca her iki bağlılık türünün örgüte yönelik bir tutum olması sebebiyle, VP'nin örgüte destek boyutunu yordayacağ1 denencesi test edilecektir. Dolayısıyla,

Hipotez 4: Duygusal bağlılık, üçlü VP sınıflaması içinde Örgüte Destek boyutunu; ikili VP sınıflaması içinde ÖVD-Ö boyutunu yordayacaktır.

Hipotez 5: Normatif bağlılık, üçlü VP sınıflaması içinde Örgüte Destek boyutunu, ikili VP sınıflaması içinde ÖVD-Ö boyutunu yordayacaktır.

\section{Örgütsel Adalet ve VP}

Örgütsel adalet konusundaki ilk araştırmalarda ağırlıklı olarak, maaş artışı ve terfi gibi sonuçların paylaşılmasını içeren bölüşümsel adalete odaklanılmıştır (Ambrose, 2002). Bölüşümsel adalet, bir takım örgütsel sonuçlara verilen bilişsel, duygusal ve davranışsal tepkileri içermektedir (Cohen-Charash ve Spector, 2001). İşlemsel adalet, örgütsel süreçlerin adaletli olmasını içermektedir ve çalışanların gözünde çoğu durumda bölüşümsel adaletten daha önemlidir (Lind ve Tyler, 1988). Cohen-Charash ve Spector (2001) tarafından yapılan meta-analiz çalışmasında ÖVD'nin, bölüşümsel ve işlemsel adaletin sonucu olarak yapıldığı belirtilmiştir. Örgütsel adaleti tek bir değişken olarak ele alan Polat ve
Celep (2008), öğretmen örnekleminden veri toplayarak gerçekleştirdikleri çalışmalarında, uluslararası alanyazın ile tutarlı olarak, ÖVD ile adalet arasında .43 değerinde bir ilişki bulmuşlardır. Örgütsel adalet ve VP arasındaki ilişki sosyal mübadele temelinde ele alınabilir. Bireyler adil veya adil olmayan uygulamalara sosyal mübadele prensipleri (Blau, 1964) doğrultusunda tepki verirler. Organ'a (1988) göre özellikle işlemsel adalet hisseden çalışanlar ÖVD sergilerler. Yazına genel olarak bakıldığında, çalışanların işlemsel adalet konusunda örgütü sorumlu; bölüşümsel adalet konusunda ise yöneticileri sorumlu tuttukları görülmektedir (örn., Blader ve Tyler, 2003; Cropanzano, Prehar ve Chen, 2002; Olkkonen ve Lipponen, 2006; Takleab, Takeuchi ve Taylor, 2005). Bu yüzden bu araştırmada diğer adalet çeşitleri arasından yordayıcı olarak işlemsel adalet seçilmiştir. Dolayısıyla, Hipotez 6: İşlemsel adalet, üçlü VP sınıflaması içinde Örgüte Destek boyutunu, ikili VP sınıflaması içinde ÖVD-Ö boyutunu yordayacaktır.

\section{Kişilik ve VP}

Kişilik ile çeşitli iş davranışları arasındaki ilişki ağırlıklı olarak Beş Büyük kişilik modeli (Costa ve McCrae, 1992a, 1992b; Goldberg, 1990, 1992) çerçevesinde incelenmektedir. Belirli kişilik boyutlarının farklı mesleki gruplarda iş performansının boyutlarını yordad1ğını gösteren araştırmalar (örn., Barrick ve Mount, 1991; Hough, Eaton, Dunnette, Kamp ve McCloy, 1990; Salgado, 1997; Tett, Jackson, Rothstein ve Reddon, 1994) sonucu İş ve Örgüt Psikolojisinde kişiliğe olan ilgi artmıştır. Söz konusu kişilik boyutları arasında şüphesiz en ön plana çıkanı öz-disiplin ve uyumluluktur.

Öz-disiplinin hem görev performansını (örn., Ones, Viswesvaran ve Schmidt, 1993) hem de ÖVD veya alt boyutlarını yordadığ1 gösterilmiştir (örn., Hurtz ve Donovan, 2000; Miller, Griffin ve Hart, 1999; Neuman ve Kickul, 1998; Organ ve Ryan, 1995). Bu araştırmalarda genellikle .20 ile .40 arasında değişen korelasyonlar rapor edilmiştir. Bu korelasyon farklılıklarının muhtemel bir sebebi kullanılan ölçme araçlarında ve/veya kullanılan ÖVD tanımlamasındaki farklılıklardır (Borman, Penner ve ark., 2001).

Uyumluluk ile ÖVD arasındaki ilişki ise biraz daha karmaşıktır. Borman, Penner ve arkadaşları (2001) tarafindan yapılan meta-analizde, yedi çalışmada uyumluluk ile genel ÖVD veya bir takım alt boyutları arasında -.28 ile .34 arasında değişen korelasyonlar elde edilmiştir. Uyumluluğun bazı ÖVD boyutları ile pozitif, bazı boyutlar ile negatif korelasyon göstermesi ÖVD ile çift yönlü bir ilişki içinde olduğunu göstermektedir (LePine ve Van Dyne, 2001). Kişilerarası ilişkiler ile bağlantılı ÖVD boyutları (örn., elseverlik, nezaket) ile uyumluluk arasında pozitif ilişki; dile getirme davranışları ile ise 
negatif ilişki bulunmuştur (LePine ve Van Dyne, 2001). Diğer çalışmaların çoğunda uyumluluk ile ÖVD veya boyutları arasında .11 ile .30 arasında değişen korelasyonlar rapor edilmiştir (örn., Borman, Penner ve ark., 2001; Ilies, Fulmer, Spitzmuller ve Johnson, 2009; Organ ve Ryan, 1995). Türkiye'de yapılan bir çalışmada ise (Çarıkçı, Kanten ve Kanten, 2010), örneğin, ÖVD ile öz-disiplin ve uyumluluk arasındaki ilişkilerin sırasıyla .54 ve .46 olduğu görülmektedir.

Son olarak Ilies ve arkadaşları (2009) tarafindan yapılan meta-analizde ÖVD-D ve ÖVD-Ö'nün kişilik açısından öncüllerinin farklı olup olmadı̆̆ test edilmiş ve öz-disiplinin ÖVD-Ö’nün ( $p=.31)$, uyumluluğun ÖVD-D'nin $(p=.21)$ yordayıcısı olduğu rapor edilmiştir. VP'nin ikili sınıflaması içinde düşünülecek olursa yukarıdaki bulgular mantıklıdır. Uyumluluğun VP'nin üçlü sınıflaması içinde kişilerarası destek ile, ikili sınıflaması içinde ÖVD-D ile ilişkili çıkması beklenebilir. Öz-disiplinin de VP'nin ikili sınıflaması içinde ÖVD-Ö ile, üçlü sınıflaması içinde ise öz-disiplinli inisiyatif ile ilişkili çıkması beklenebilir. Öz-disiplinli çalışanlar dikkatli, sorumlu ve titiz çalışanlardır. Ayrıca öz-disiplin boyutu çalışkanlık, düzenlilik ve öz-kontrol gibi özellikleri de içermektedir. Çalışanın işini daha iyi yapmak için göstereceği çaba tüm bu özelliklerden olumlu etkilenecektir. Kusursuz iş yapmak isteyen bir çalışanın ekstra çaba göstermesi gerekecektir; sorumluluk hisseden bir çalışan kendisini geliştirmek için ekstra çaba göstermeye eğilimli olacaktır. Öz-disiplinli inisiyatif, bir yandan da görev performansına en çok yaklaşan VP boyutudur. Öz-disiplinli çalışanlar düzenli ve planlı oldukları için, öz-disiplini düşük çalışanlara k1yasla daha fazla zaman kazanmakta ve görevlerini bu yüzden daha etkili yerine getirebilmektedir. Benzer bir mantığ 1 kullanarak öz-disiplini yüksek olan çalışanların görev performansının ötesine geçen davranışlar olan öz-disiplinli inisiyatif davranışlarını gösterecekleri beklenebilir. Uyumluluğun ise en yüksek yordama gücü olduğu durum, önemli derecede kişilerarası etkileşim içeren ve diğerlerine yardım etme ile onlarla iş birliği yapmanın işin gereği olarak karşımıza çıktığ durumdur (Barrick, Stewart, Neubert ve Mount, 1998; Mount, Barrick ve Stewart, 1998). Konuya bir başka açıdan yaklaş1lacak olursa, tartışmacı, kat1, diğerlerini önemsemeyen ve hoşgörüsüz çalışanların iyi bir takım üyesi olması çok zordur (Barrick, Mount ve Judge, 2001). Dolayisiyla,

Hipotez 7: Öz-disiplin, üçlü VP sınıflaması içinde Öz-disiplinli İnisiyatif boyutunu, ikili VP sınıflaması içinde ÖVD-Ö boyutunu yordayacaktır.

Hipotez 8: Uyumluluk, üçlü VP sınıflaması içinde Kişilerarası Destek boyutunu, ikili VP sınıflaması içinde ÖVD-D boyutunu yordayacaktır.

\section{Grup Sargınlı̆̆l ve VP}

Grup sargınlığ1, Festinger (1950) tarafindan, “grup üyelerinin grup üyesi olarak kalmasını sağlayan güçler" olarak tanımlanmıştır (s. 274). Sargın gruplardaki üyeler diğerlerine karşı daha hassas olmakta ve diğer üyelere yardım etme eğilimi göstermektedir (Schachter, Ellertson, McBride ve Gregory, 1951). Sargınlık, temelde grup üyesi olarak kalma niyetini içerdiği için, sargın olmayan gruplara kıyasla sargın gruplarda üyelerin birbirleri ile daha fazla iletişim kuracağ , birbirleri üzerinde daha fazla etkiye sahip olacakları iddia edilebilir (Kidwell ve ark., 1997).

Organ (1990) tarafindan, vatandaşlık davranışlarının ekonomik olmaktan çok sosyal bir mübadele gereği, grup üyelerine ve genel olarak da örgüte olumlu karşıllk verme olarak nitelendirilebileceği söylenmiştir. Ayrıca, Van Dyne ve arkadaşları (1994) ve Kidwell ve arkadaşları (1997) tarafından da grup sargınlığı ÖVD ve benzeri davranışların önemli bir öncülü olarak tanımlanmıştır. Sargınlığı yüksek gruplar üyelerinde güçlü bir sosyal aidiyet yaratmakta ve bu aidiyet sebebiyle üyeler birbirlerine yardım etme ve benzeri davranışları sergilemektedirler. Sargınlık ayrıca, grup üyelerinin duygudurumlarında yaptığı olumlu etkiler sebebiyle de ÖVD ve benzeri davranışları tetiklemektedir (George ve Bettenhausen, 1990). Sargınlığın diğer kișilere ve grup üyelerine yönelik olması sebebiyle,

Hipotez 9: Grup sargınlığı, üçlü VP sınıflaması içinde Kişilerarası Destek boyutunu, ikili VP sınıflaması içinde ÖVD-D boyutunu yordayacaktır.

\section{Issle Bütünleşme}

İşle bütünleşme psikolojik bir özdeşleşme süreci içermektedir ve işi ile bütünleşen çalışanlar, işi kimliklerinin önemli bir boyutu olarak değerlendirmektedir (Kanungo, 1982). Bu tanım çalışanın psikolojik bütünleşmeye ilişkin bilişini içermektedir. İşle bütünleşmenin çalışanın güdülenmesi (örn., Lawler, 1986), kişisel ilerlemesi ve doyumu (örn., Hackman ve Lawler, 1971; Kahn, 1990) ile yakından ilişkili olduğu bilinmektedir. Bass'a (1965) göre işle ilgili karar almada özerklik, örgüte katkıda bulunulduğu hissi, takdir edilme, başarı gibi etkenler işle bütünleşmeye yol açmaktadır. Katz ve Kahn'a (1978) göre çalışanın örgütünün taleplerini kabul edebilmesi için işle bütünleşme bir ön şarttır. İşi ile bütünleşenler örgütün hedeflerini içselleştirirler. Doyum ile performans arasındaki ilişki, işi ile bütünleşenler için daha kuvvetlidir. Çalışanların işleri ile bütünleşmesi, ağırlıklı olarak, belirgin psikolojik ihtiyaçlarının işi aracılığı ile karşılanmasına bağlıdır (Kanungo, 1982). İşle bütünleşme ile ilgili en kapsamlı çalışmalardan birisi Brown (1996) tarafindan yapılan meta-analizdir. Brown (1996) bu çalışmasına işle bütünleşmenin öncülleri, ilişkili de- 
ğişkenleri ve sonuçlarını içeren çalışmaları dâhil etmiştir. $\mathrm{Bu}$ çalışmaya göre, işle bütünleşmenin sonuçları olarak ele alınan değişkenlerden en yüksek ilişki gösterenler iş doyumu, örgütsel bağlılık ve çaba düzeyidir. Brown'ın (1996) çalışmasından elde edilen bir ilginç bulgu ise işle bütünleşme ile görev performansı arasında anlamlı bir ilişki bulunamamasıdır. Diefendorff ve arkadaşları (2002) ise yazında işle bütünleşme ile ÖVD arasındaki ilişkiyi inceleyen ilk araştırmacılar olmuşlardır. Bu araştırma sonucunda işle bütünleşmenin elseverlik, vatandaşlık bilinci ve öz-disiplin boyutları ile doğrudan, lütufkârlık ve sportmenlik boyutları ile ise cinsiyet tarafından değişimlenen dolaylı ilişkisi olduğu ortaya çıkmıştır.

İşle bütünleşmenin hem tanımına hem de öncüllerine bakıldığı zaman, işi ile daha fazla bütünleşen çalışanların fazladan çaba göstermeye ve yetkinliklerini işlerini daha verimli yapmak için kullanmaya daha yatkın olacaklarını düşünebiliriz. Bu davranışlar VP'nin üçlü yapısı içinde öz-disiplinli inisiyatif, ikili yapı içinde ise ÖVD-Ö boyutu içinde kapsandığı için aşağıdaki denence oluşturulmuştur.

Hipotez 10: İşle bütünleşme üçlü VP modeli içinde Özdisiplinli İnisiyatif boyutunu, ikili VP modeli içinde ÖVD-Ö’yü yordayacaktır.

\section{Yöntem}

\section{Katılımcılar ve İşlem}

Araştırmanın bu aşamasına Türkiye'nin 21 farklı ilinden 660 çalışan katılmıştır. Katılımcıların \%80'inden fazlası büyükşehirlerde (Ankara, İstanbul, İzmir, Bursa, Adana) çalışmaktadır. Analizlere geçmeden önce veriler tekli ve çoklu bağlantı sayıltıları açısından değerlendirilmiş ve aşırı değerlere sahip veya toplam maddelerin $\% 5$ 'inden fazlasını boş bırakan katılımcılar çıkarıldıktan sonra analizler 619 katılımcı üzerinden yapılmıştır.

Katılımcıların 269'u kadın (\%43.5), 345'i erkektir (\%55.7); 322'si kamu sektörüne (\%52), 285'i özel (\%46) sektöre ait işyerlerinde tam zamanlı çalışmaktadır. Katılımcıların yaş ortalaması $34.47(\mathrm{~S}=9.26)$ yıl; ortalama çalışma süresi 12.17 ( $\mathrm{S}=8.85)$ yıldır. Katılımcıların 198'si lise (\%32), 60’1 ön lisans (\%9.7), 280'i yüksekokul veya üniversite $(\% 45.2)$ ve 71 'i lisansüstü (\%11.5) eğitim seviyesine sahiptir.

Araştırma için gerekli izinler alındıktan sonra ölçekler karışık bir sırada ve zarflar içinde katılımcılara sunulmuştur. Kartopu tekniği ile ulaşılan katılımcılar ölçekleri bireysel olarak doldurmuştur ve veriler araştırmac1lara iletilmiştir.

\section{Veri Toplama Araçları}

$\mathrm{Bu}$ çalışmada, bir önceki çalışmada bilgileri verilen VP, iş doyumu, işle bütünleşme ve grup sargınlığı ölçeklerine ek olarak, örgütsel adalet, örgütsel bağlılık ve kişilik ölçekleri kullanılmıştır. İş doyumu ölçeğinin, araştırma denenceleri ile tutarlı olarak, yöneticiden duyulan doyum, işin doğasından duyulan doyum ve çalışma arkadaşlarından duyulan doyum boyutlarını ölçen maddeleri kullanılmıştır.

Örgütsel Adalet Ölçeği. Colquitt (2001) tarafından oluşturulan ve Karabay (2004) tarafindan Türkçeye uyarlanan ölçeğin işlemsel adaleti ölçen dört maddesi kullanılmıştır. Maddeler soru şeklinde düzenlenmiştir ve katılımcılar bu soruları beşli Likert tipi cevap skalası (1 = Hiç Yansitmıyor, 5 = Tamamen Yansitıyor) ile yanıtlamıştır. Ölçeğin Karabay (2004) tarafindan rapor edilen Cronbach alfa değeri .89'dur.

Örgütsel Bağlılık Ölçeği. Allen ve Meyer (1990) tarafindan geliştirilen ve Wasti (2003) tarafindan revize edilerek Türkçeye uyarlanan ölçeğin duygusal bağll1ık ( 8 madde) ile normatif bağlılık (10 madde) maddeleri kullanılmıştır. Maddeler katılımcılar tarafından beşli Likert tipi cevap skalası $(1=$ Hiç Katılmıyorum, 5 = Kesinlikle Katılıyorum) ile değerlendirilmiştir. Bu iki boyut için Wasti (2003) tarafindan rapor edilen Cronbach alfa değerleri sırasıyla .83 ve .87 'dir.

Kişilik Ölçeği. Kişilik ölçümü almak için beş faktör kişilik modeli çerçevesinde geliştirilmiş ölçeklerden birisi olan BFI (Big Five Inventory, Benet-Martinez ve John, 1998) kullanılmıştır. BFI'ın - Türkiye dâhil farklı kültürlerde tutarlı bir şekilde işlediği daha önceki araştırmalarda gösterilmiştir (Schmitt ve ark., 2003). Sümer ve Sümer (2003) tarafından Türkçeye uyarlaması yapılan ölçeğin öz-disiplin (9 madde) ve uyumluluk (9 madde) boyutlarını ölçen maddeleri kullanılmıştır. İki boyutun güvenirlik katsayıları sırasıyla .77 ve .64'dür. Maddeler katılımcılar tarafından beşli Likert tipi cevap skalası (1=Hiç Katılmıyorum, 5=Kesinlikle Katılıyorum) üzerinde değerlendirilmiştir.

\section{Bulgular}

Bu bölümde ilk olarak, VP'nin faktör yapısı ile ilgili analizler, üçüncü çalışmada yer alan tüm ölçeklere uygulanan DFA ve son olarak VP'nin seçilen faktör yapısına uygun olarak öncülleri ile ilişkisi raporlanmiştır.

Vatandaşlık Performansının Yapısı. VP'nin çok boyutlu bir kavram olarak yapısını değerlendirebilmek için, bir önceki çalışmada toplanan veriler $(n=213)$ ile bu çalışmanın verileri $(n=619)$ birleștirilmiștir. Toplam 832 kişilik bir örneklemde VP'nin üçlü, ikili ve tek faktörlü yapıları Lisrel 8.54 (Jöreskog ve Sörbom, 2003) programı kullanılarak yapılan DFA ile sınanmıştır. DFA sonuçlarına göre, tüm faktör yüklerinin $t$ değerleri anlamlıdır $(p<.05)$. DFA modeli ile verilerin uyumunu test 
Tablo 3. Vatandaşlık Performansı Ölçeğine Uygulanan DFA Uyum İndeksleri

\begin{tabular}{|c|c|c|c|c|c|c|c|c|c|c|c|}
\hline Model & $\mathrm{sd}$ & $\chi^{2}$ & $\begin{array}{c}\mathrm{p} \\
\text { (tam } \\
\text { uyum) }\end{array}$ & $\begin{array}{c}\mathrm{P} \\
\text { (yakın } \\
\text { uyum) }\end{array}$ & RMSEA & $\begin{array}{r}\text { RM } \\
\text { G } \\
\text { Ara }\end{array}$ & $\begin{array}{l}\text { EA } \\
\text { ven } \\
\text { klar1 }\end{array}$ & ECVI & CFI & TLI & AIC \\
\hline Yokluk & 105 & $12584 * *$ & .00 & .00 & - & - & - & 15.36 & - & - & \\
\hline A-Üçlü M. & 87 & $388.6 * *$ & .00 & .00 & .068 & $(.061$ & $.075)$ & 0.57 & .97 & .97 & 466.6 \\
\hline B-İkili M. & 89 & $574.74 * *$ & .00 & .00 & .085 & $(.078$ & $.092)$ & 0.79 & .96 & .96 & 648.74 \\
\hline C-Tekli M. & 90 & $1093.72 * *$ & .00 & .00 & .121 & $(.11$ & $.13)$ & 1.42 & .94 & .92 & 1165.72 \\
\hline
\end{tabular}

Karşılaştırmalı Uyum İndeksleri

\begin{tabular}{|c|c|c|c|c|c|c|c|c|c|}
\hline Model & $\Delta \mathrm{sd}$ & $\Delta \chi^{2}$ & & & $\Delta$ RMSEA & $\Delta \mathrm{ECVI}$ & $\Delta \mathrm{CFI}$ & $\Delta \mathrm{TLI}$ & $\Delta \mathrm{AIC}$ \\
\hline$A-B$ & 2 & $186.14 * *$ & - & - & .02 & 0.22 & -.01 & -.01 & 182 \\
\hline$A-C$ & 3 & $705.12 * *$ & - & - & .05 & 0.85 & -.03 & -.05 & 699 \\
\hline$B-C$ & 1 & $518.98 * *$ & - & - & .04 & 0.63 & -.02 & -.04 & 517 \\
\hline
\end{tabular}

Not. $N=832,{ }^{* *} p<.01$; RMSEA = Yaklaşık hataların ortalama karekökü; ECVI = Beklenen çapraz geçerlik indeksi; CFI $=$ Karşılaştırmalı uyum indeksi; TLI = Tucker-Lewis indeksi; AIC = Akaike bilgi ölçütü.

etmek için ki-kare, ki-kare/s.d., p-tam uyum, p-yakın uyum, RMSEA, CFI ve TLI değerleri incelenmiştir. Model ile veriler arasındaki uyuma ilişkin bulgular Tablo 3'de gösterilmiştir.

Tablo 3'den de görülebileceği gibi, üç model karşılaştırıldığında $\chi^{2}$, RMSEA, ECVI, CFI, TLI ve iç içe olmayan (non-nested) modelleri karşılaştırmak için kullanılan AIC değerleri açısından en iyi model üçlü sınıflamayı içeren Model A'dır. Üçlü sınıflamayı içeren Model A $\chi^{2}$ değeri açısından diğer iki modelden daha iyidir. Üç modelin de $\chi^{2}$ değeri anlamlı olduğu halde birden fazla modelin karşılaștırıldığı durumlarda $\chi^{2}$ değișimleri önemli bir istatistiksel ölçüt olarak kullanılmaktadır. RMSEA en önemli uyum indeksi değerlerinden birisidir ve .06 'nın altındaki değer iyi uyum, .08'in altındaki değerler ise yeterli uyuma işaret etmektedir (Hu ve Bentler, 1999). RMSEA değerinin alt ve üst güven aralıklarının her ikisinin de .08'in altında olması gerekmektedir. Bu ölçütlere göre yeterli uyum gösteren tek model üçlü s1nıflama modelidir. İç içe olmayan Alternatif modellerin test edildiği durumlarda, modellerden hangisinin daha iyi uyum gösterdiğini anlamak için başvurulan değerler ise ECVI ve AIC'dir. Diğer şeyler sabit tutulduğunda ECVI ve AIC değeri en düşük olan alternatifin diğerlerinden üstün olduğu kabul edilmektedir (Kline, 2005). Hem ECVI hem de AIC değeri açısından da en iyi mo- delin üçlü sınıflama modeli olduğu görülmektedir. Her üç model de CFI ve TLI değerleri açısından iyi uyuma sahip olsa da bu üç değer açısından da üçlü modelin diğerlerinden daha iyi uyum gösterdiği söylenebilir. Son olarak üç modelin standardize edilmiş RMSR değerleri incelendiğinde üçlü, ikili ve tek faktörlerin sırasıyla $.05, .064$ ve .075 değerlerini aldıkları görülmektedir. Her üç model de kritik değer olan .08' in (Hu ve Bentler, 1999) altında olmasına rağmen, bu indeks açısından da en iyi modelin üçlü sınıflama modeli olduğu görülmektedir. Yukarıda belirtilen uyum indeksleri doğrultusunda, VP'nin üç alt boyuta sahip bir değişken olarak ele alınmasına karar verilmiştir ve bundan sonraki analizler bu yapı doğrultusunda gerçekleştirilmiştir. Dolayısıyla, araştırma denencelerinden sadece üçlü sınıflama doğrultusunda oluşturulmuş olanlar yapısal eşitlik modeli ile test edilmiştir. Böylece ölçme hatalarının etkisi ortadan kaldırılmıştır ve yordayıcılar arasındaki kovaryansın etkisi kontrol edilmiştir (Klein, 2015).

VP'nin öncüllerine ilişkin oluşturulan denenceleri sınamaya geçmeden önce, asıl çalışmada yer alan tüm değişkenler ile Lisrel 8.54 (Jöreskog ve Sörbom, 2003) programı kullanılarak DFA yapılmıştır. DFA sonuçlarına göre, tüm faktör yüklerinin $t$ değerleri anlamlıdır $(p<$ $.05)$. Model ile veriler arasındaki uyuma ilişkin bulgular Tablo 4'de gösterilmiştir. 
Tablo 4. Üçüncü Çalışmada Yer Alan Değişkenlere Uygulanan DFA Uyum İndeksleri

\begin{tabular}{|c|c|c|c|c|c|c|c|c|c|c|}
\hline Model & $\mathrm{sd}$ & $\chi^{2}$ & $\begin{array}{c}\mathrm{p} \\
\text { (tam } \\
\text { uyum) }\end{array}$ & $\begin{array}{c}\mathrm{P} \\
\text { (yakın } \\
\text { uyum) }\end{array}$ & RMSEA & $\begin{array}{r}\text { RN } \\
\text { Gi } \\
\text { Ara }\end{array}$ & $\begin{array}{l}\text { EA } \\
\text { en } \\
\text { klar1 }\end{array}$ & ECVI & CFI & TLI \\
\hline Yokluk Modeli & 9180 & $218333 * *$ & .00 & - & - & - & - & 353.73 & - & - \\
\hline DFA & 8813 & $17641 * *$ & .00 & 1.00 & .044 & $(.043$ & $.045)$ & 32.86 & .96 & .96 \\
\hline
\end{tabular}

Not. $N=619,{ }^{* *} p<.01$; RMSEA=Yaklaşık hataların ortalama karekökü; ECVI = Beklenen çapraz geçerlik indeksi; CFI = Karşılaştırmalı uyum indeksi; $\mathrm{TLI}=$ Tucker-Lewis indeksi

Tablo 5. Vatandaşlık Performansının Öncüllerine İlişkin Yapısal Eşitlik Modeli Analizleri

\begin{tabular}{|c|c|c|c|c|c|c|c|c|c|c|}
\hline Model & sd & $\chi^{2}$ & $\begin{array}{c}\mathrm{p} \\
\text { (tam } \\
\text { uyum) }\end{array}$ & $\begin{array}{c}\mathrm{P} \\
\text { (yakın } \\
\text { uyum) }\end{array}$ & RMSEA & $\begin{array}{r}\text { RN } \\
\text { Gi } \\
\text { Ara }\end{array}$ & $\begin{array}{l}\text { EA } \\
\text { en } \\
\text { klar1 }\end{array}$ & ECVI & CFI & TLI \\
\hline Yokluk & 3655 & $110384 * *$ & .00 & .00 & - & - & - & 178 & - & - \\
\hline A-Üçlü M. & 3514 & $8302 * *$ & .00 & .37 & .050 & $(.049$ & $.052)$ & 15.3 & .96 & .95 \\
\hline
\end{tabular}

Not. $N=619,{ }^{*} p<.01$; RMSEA = Yaklaşık hataların ortalama karekökü; ECVI = Beklenen çapraz geçerlik indeksi; CFI=Karşılaştırmalı uyum indeksi; TLI $=$ Tucker-Lewis indeksi; NFI = Normlaştırılmış uyum indeksi; AIC = Akaike bilgi ölçütü

Yapılan doğrulayıcı faktör analizinde model ile veriler arasındaki uyumu değerlendirmek için ilk olarak ki-kare testi kullanılmış ve bu değerin anlamlı olduğu görülmüştür $\left(\chi^{2}(8813, N=619)=17641, p<.001\right)$. Modelin uygunluğunu değerlendirebilmek için $\chi^{2} /$ s.d., RMSEA, ECVI, CFI ve TLI değerlerine odaklanılmıştır. Tablo 4'de ayrıntıları verilen bu değerler, iyi uyuma işaret etmiştir ve öncüllere ilişkin modelin test edilmesi aşamasına geçilmiştir.

Vatandaşlık Performansının Öncülleri. Bir önceki aşamada yapılan analizler doğrultusunda, VP'nin üç faktörlü yapısına ilişskin denenceler bu aşamada sınanmıştır. Üç faktörlü modelin öncüllerine ilişkin yapısal eşitlik modeli ile yapılan analizlerin sonuçları Tablo 5'te sunulmuştur. Öncüllerin, VP ile olan ilişkisi Şekil 1 'de sunulmuştur. Sunum kolaylığı sağlaması açısından, şekillerde ölçüm modeline ilişkin değerler gösterilmemiştir. Ölçüm modeli içinde yer alan maddelerin ilgili faktörlerden aldığı yükler anlamlıdır $(p<.05)$. Asıl çalışmada kullanılan değişkenlerin ortalamaları, standart sapmaları, güvenirlik katsayıları ile değişkenler arası korelasyonlar ise Tablo 6'da gösterilmiştir.

Şekil 1'de gösterilen model öncülleri ile olan ilişkisi açısından incelenecek olursa, kişilerarası destek boyutunu yordaması beklenen çalışma arkadaşlarından doyum ile örgüte destek boyutunu yordaması beklenen işlemsel adaletin anlamlı beta değerleri almadıkları görülmektedir. Dolayısıyla H1 ve H6 desteklenmemiştir. Model çerçevesinde kişilerarası destek boyutu uyumluluk $(\beta=.33, p<.01)$ ve grup sargınlığ1 $(\beta=.21, p<.01)$ değişkenleri tarafından yordanmaktadır. Dolayısıyla H8 ve H9 desteklenmiştir. Örgüte destek boyutu yöneticiden doyum $(\beta=.15, p<.01)$, duygusal bağl1lık $(\beta=.32, p<$ $.01)$ ve normatif bağl1lık $(\beta=.30, p<.01)$ değişkenleri tarafından yordanmaktadır. Buna göre, H2, H4 ve H5 denenceleri desteklenmiştir. Öz-disiplinli inisiyatif boyutu ise işin doğasından doyum $(\beta=.17, \mathrm{p}<.01)$, öz-disiplin $(\beta=.25, p<.01)$ ve işle bütünleşme $(\beta=.25, p<.01)$ boyutları tarafindan yordanmaktadır. Dolayısıyla, H3, $\mathrm{H} 7$ ve $\mathrm{H} 10$ denenceleri de desteklenmiştir. 


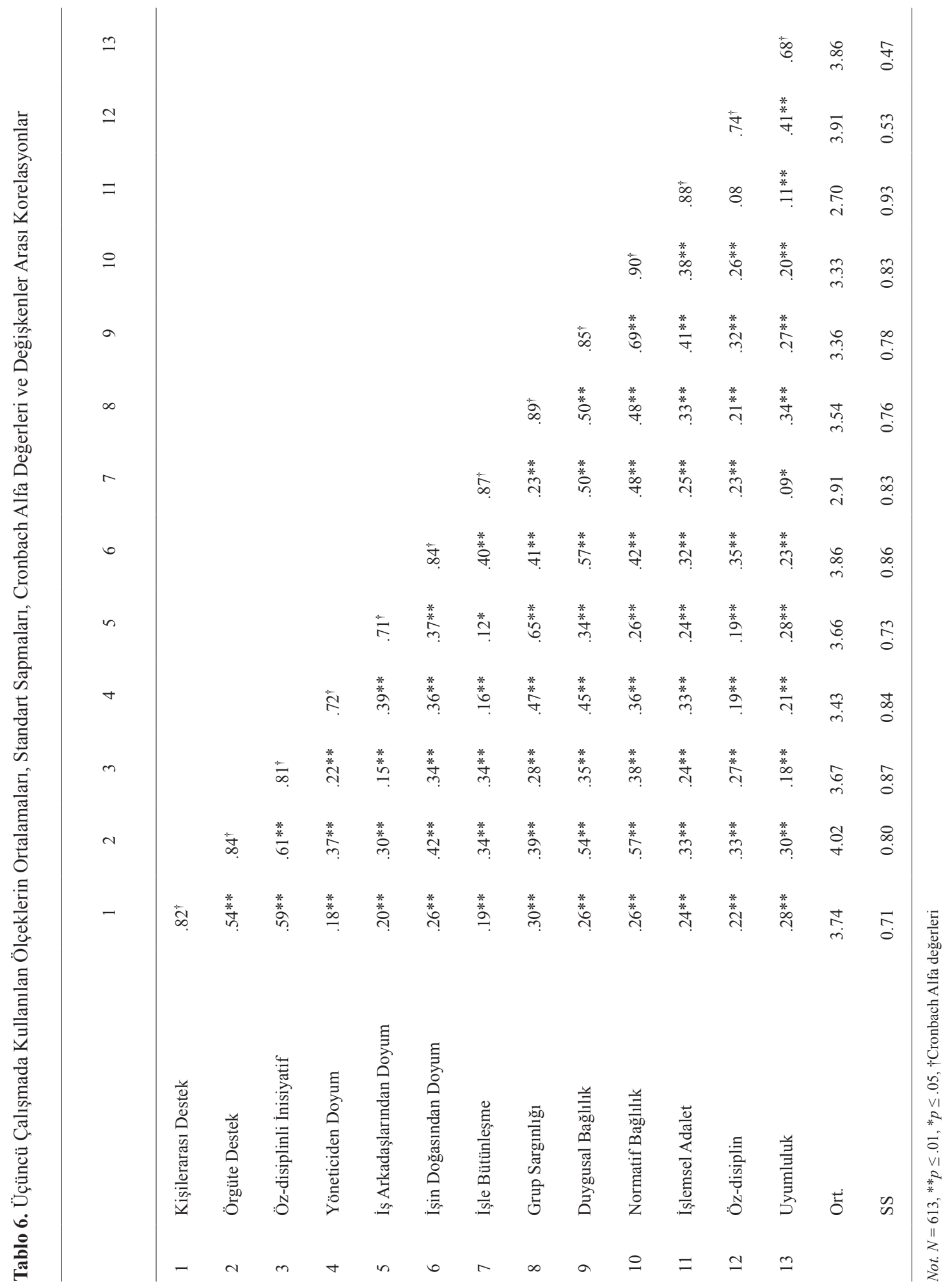




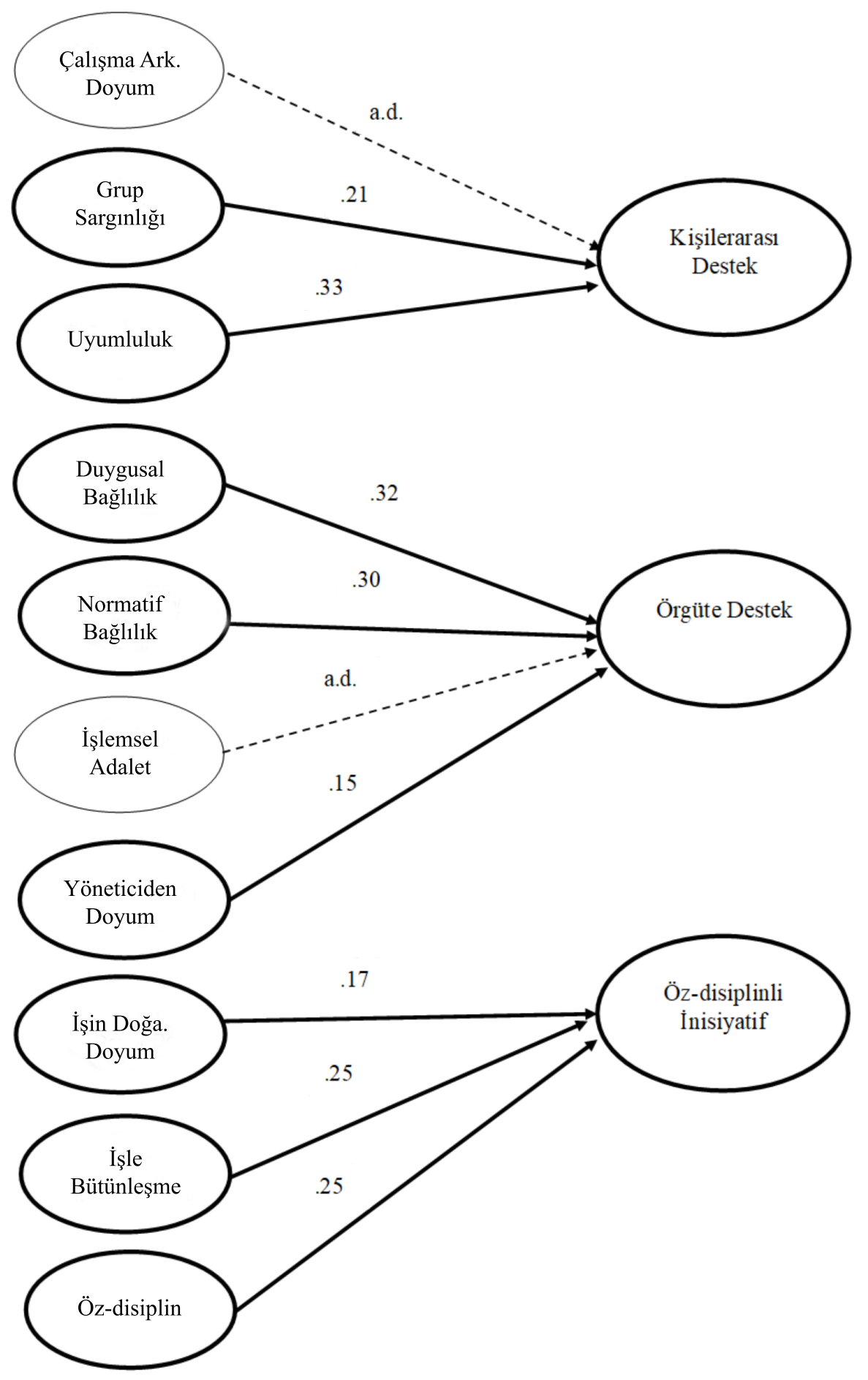

Şekil 1. Vatandaşlık Performansının Öncülleri 


\section{Genel Tartışma}

$\mathrm{Bu}$ araştırmanın amacı, örgütlerin işleyişinde ve çalışanların iş hayatlarında çeşitli açılardan çok önemli bir yer tutan vatandaşlık performansı davranışlarını Türkiye'de incelemektir. Bu araştırmada VP'nin görünüş, kapsam ve yapı geçerliği çalışmaları yapılmış; yazında yer alan kuramsal tartışmalara cevap olabilecek şekilde, VP'nin uygun çok boyutlu kavramsallaştırmasına ilişkin analizler yapılmış ve VP boyutlarının birbirinden farklı öncüllere sahip olup olmadığı test edilmiştir.

Birinci çalışmada, VP'nin tanımının anlaşılır olduğu, tanım çerçevesinde ölçme aracının yeterli derecede kapsam geçerliğine sahip olduğu görülmüştür. Hem ölçek geliştirme uygulamalarında (örn., MacKenzie ve ark., 2011) hem de kuram test etmeyi içeren araştırmalarda (örn., Shaffer ve ark., 2016) kavram tanımı konusunda eksiklikler olduğu bilinmektedir. Bu açıdan bakıldığında, araştırmada yer alan birinci çalışmamızın önemli olduğu söylenebilir. Birinci çalışmada kullanılan yarı-yapılandırılmış görüşme tekniği ile Coleman ve Borman (2000) tarafindan derlenen davranışlara yerel-kültürel bir ekleme yapılmasına gerek olmadığ 1 görülmüştür. Gönüllülük ve iş birliği içeren, sosyal mübadele çerçevesinde gösterilen ve yatkınlıkların önemli olduğu vatandaşlık davranışlarının her iş için ortak olduğu iddia edilmektedir (Van Scotter ve Motowidlo, 1996). Ancak, makalede sunulan görünüş ve kapsam geçerliği kanıtları, örneklemimizin heterojenliği ve küçüklüğü çerçevesinde değerlendirilmelidir. Her ne kadar farklı özelliklere sahip on katılımcıdan gelen bilgiler doygunluk gösterse de (Gaskell, 2000), elde edilen kanıtlar örneklemimiz çerçevesinde değerlendirilmelidir.

VP kavramının, araştırmamızda yer alan ikinci çalışma çerçevesinde, başka değişkenlerle beklenen ilişkiler gösterdiği görülmüştür. İkinci çalışmanın kuvvetli yönlerinden bir tanesi, ayırt edici geçerliği değerlendirmek için seçilen değişkenlerin farklı alanlardan olmasıdır. Çalışma hayatı, iş hayatı ve diğer hayat alanlarına ilişkin ölçümler alınmış ve ölçümlerle VP ölçeğinin gösterdiği pozitif, negatif ve anlamsız ilişkiler raporlanmıştır. Bu açıdan ikinci çalışmanın, ölçek geliştirme ile ilgili klasik kaynaklarda (örn., Bagozzi ve Edwards, 1998; DeVellis, 2016; MacKenzie ve ark., 2011) verilen tavsiyeler doğrultusunda tasarlandığı söylenebilir. İkinci çalışmanın özgün yanlarından biri olarak, çalışmada kullanılan işin merkeziliği ölçümü gösterilebilir. Çalışma kavramına verilen göreli önem, yazarların bildiği kadarıyla, önceki araştırmalarda vatandaşlık davranışları ile ilişkisi doğrudan incelenen bir kavram değildir. Çalışma ve diğer hayat alanlarına verilen önem, ilerideki vatandaşlık veya diğer örgütsel davranışları içeren çalışmalarda etkisi incelenecek bir değişken olabilir. Benzer bir şekilde hem ikinci hem de üçüncü çalışmada kullanılan grup sargınlığı ve işle bütünleşme kavramları da göreli olarak VP alanyazınında az incelenmiş kavramlardandır. $\mathrm{Bu}$ değişkenlerin, gelecek araştırmalarda daha fazla ilgiyi hak ettiği söylenebilir.

Üçüncü çalışmanın, daha önce belirtildiği gibi birçok amacı vardır. Yapılan analizler sonucunda, ilk olarak, VP'nin çok-boyutlu sınıflaması konusunda önemli bir katkı yapıldığı söylenebilir. Çalışmada VP ile ilgili olarak alternatif kavramsallaştırmalar tanımlanmış ve bu alternatifler aynı çalışma içinde birbirleri ile karşılaştırılarak sunulmuştur. Bu açıdan bakıldığında, makalenin kuramsal katkıları yanında alanyazına yöntemsel açıdan da katkı yaptığı söylenebilir. Çalışmada, araştırmacıların beklentisi doğrultusunda, VP için toplam model kavramsallaştırmasının göreli daha uygun olduğu görülmüştür. $\mathrm{Bu}$ sonuç, elbette, seçilen model ve ölçme aracı bağlamında değerlendirilmelidir. Daha önceki çalışmalarda vurgulanan profil modeli (LePine ve ark., 2002; Motowidlo, 2000), ÖVD ve bağlamsal performans modelleri için geçerli olabilir. Ancak, üçlü VP modelini bundan sonra kullanacak araştırmacıların, bu araştırmadan üretilen bilgileri kullanması uygun olabilecektir. Daha açık bir şekilde belirtmek gerekirse, bu çalışmada Türkçe alanyazına kazandırılan VP ölçümünün, tek bir değişken olarak değil, ayrı boyutlar olarak ele alınması daha uygun olacaktır.

Üçüncü çalışmanın önemli katkılarından bir tanesi de farklı kuramsal bakış açılarını bir araya getirerek on farklı öncülle bir model oluşturması ve test etmesidir. Üçüncü çalışmada geliştirilen denenceler, bir model çerçevesinde ve bir arada incelenmiştir. Bu incelemeyi yaparken, araştırmanın doğasına uygun olan yapısal eşitlik modeli kullanılmış böylece ölçme hatalarının etkisi ortadan kaldırılmış ve yordayıcılar arasındaki kovaryansın etkisi kontrol edilmiştir (Klein, 2015). Bu açılardan incelendiğinde, ayrı ayrı regresyon analizlerine kıyasla daha güvenilir bir analiz yapılabilmiştir.

VP'nin üçlü modelinde kişilerarası destek boyutunun öncülleri olarak grup sargınlığı ve uyumluluk; örgüte destek boyutunun öncülleri olarak duygusal bağlılık, normatif bağlllık ve yöneticiden doyum; öz-disiplinli inisiyatifin öncülleri olarak ise işin doğasından doyum, işle bütünleşme ve öz-disiplin karşımıza çıkmaktadır. VP'nin üçlü sınıflamasına ve boyutların öncüllerine ilişkin yukarıda verilen bilgiler genel olarak değerlendirildiğinde, bu sonuçların çeşitli açılardan ele alınması gerekmektedir. Neticede, bu araştırmanın önemli bir amacı da çalışanların neden VP gösterdikleri sorusunun yanıtını bulmaktır. $\mathrm{Bu}$ yanıtı bulmak için yapılan değerlendirmelerde üç temel yaklaşım vardır: sosyal mübadele kuramı, hedef benzerliği modeli ve içsel güdülenme yaklaşımı. Bu üç yaklaşıma ek olarak, kişilik değişkenleri de 
önceki araştırma bulguları doğrultusunda çalışmamızda yer almıştır.

Daha önce belirtildiği gibi, sosyal mübadele yaklaşımına göre, çalışanlar örgütleri ile ilişkilerini bilişsel olarak sürekli değerlendirmektedirler. Bu değerlendirme sonucunda, örgütlerinden, kendileri için önemli sonuçlar elde eden çalışanlar, bunun karşılığını vermeye çalışmaktadır. Bu araştırma bağlamında ele alınan iş doyumu, örgütsel bağlılık ve grup sargınlığı değişkenleri, temelde bu değerlendirme sonucu olarak çalışanın verdiği karş1lığa denk gelen kavramlardır. İşinden memnun olan, örgütüne bağl1lık hisseden ve sargın bir grupta çalışan kişiler bunun karşılığını VP sergileyerek göstermektedirler.

Üçlü VP modeli, vatandaşlık davranışlarının yöneltildiği hedefe (örgütte çalışan diğer kişiler, örgütün kendisi ve çalışanın işi) göre bir sınıflama içermektedir. Hedef benzerliği modeli çerçevesinde ele alındığında, VP'nin hem faktör yapısı hem de öncülleri ile olan ilişkisi, kuramın tezlerini desteklemektedir. Hedef benzerliği yaklaşımına göre çalışanlar iş arkadaşları, örgütleri ve kendi işlerini birbirlerinden bağımsız olarak değerlendirebilmekte ve bunlara yönelik ayrı tutumlar geliştirebilmektedir. $\mathrm{Bu}$ araştırmada vatandaşlık performansı kavramı yöneltildiği hedefe göre sınıflandığı için bir anlamda hedef benzerliği etkisini barındırmaktadır. Bundan sonraki araştırmalarda, hedef benzerliği yaklaşımının yazında daha fazla yer alması beklenebileceğinden, bu araştırmanın bu açıdan da yazına bir katkı sağladığ söylenebilir.

$\mathrm{Bu}$ araştırmanın bulgularına göre, VP'nin neden gösterildiği ile ilgili bir diğer önemli açıklama ise - dolaylı olarak - içsel güdülenme kuramından gelmektedir. Her ne kadar bu araştırmada içsel güdülenme doğrudan ölçülen bir değişken olmasa da işle bütünleşme ve işin doğasından duyulan doyum kavramlarının ortak noktası içsel güdülenme ile örtüşen kavramlar olmalarıdır. Dolayısıyla, bir takım vatandaşlık davranışlarının sergilenmesi, çalışanın belirli derecede içsel güdülenme hissedip hissetmediğine bağlıdır denilebilir. Yaptıkları işin doğasından keyif alan ve işleri ile bütünleşebilen çalışanlar, araştırma sonuçlarımıza göre daha fazla öz-disiplinli inisiyatif davranışları göstermektedir.

Son zamanlarda yazında çok popüler olan kişilik ile örgütsel davranışlar arasındaki ilişki, bu araştırmada da yansımalarını bulmuştur. $\mathrm{Bu}$ araştırmada ele alınan iki kişilik değişkeni (öz-disiplin ve uyumluluk), VP'nin önemli yordayıcıları olarak gözükmektedir. Genel olarak değerlendirmek gerekirse, yukarıdaki üç mekanizmanın, birbirlerinin varlıklarında, VP üzerinde yordama güçleri olması önemli bir bulgudur. Bu sebeple, üçüncü çalışmada, denenceler sınanırken, tüm değişkenler bir arada analiz edilmiștir. Bu analiz stratejisinin en önemli avantaj1, belirli bir boyutun öncülleri ile olan ilişkisi incelenirken, hem diğer boyutların hem de diğer öncüllerin etkisini görebilmektir. Bu strateji sonrasında, örneğin çalışma arkadaşlarından doyum ile kişilerarası destek ve işlemsel adalet ile örgüte destek arasındaki beta katsayıları anlamlı düzeyde bulunmamıştır. $\mathrm{Bu}$ değişkenler arasındaki korelasyon ise anlamlı düzeydedir. $\mathrm{Bu}$ durumun birçok olası sebebi olabilir. Bunlardan ilki kendi aralarında yüksek sayılabilecek korelasyona sahip yordayıcıların aynı anda kullanılması olabilir. Baskılama etkisi ile yordayıcılardan bir tanesi diğerinin etkisini azalmaktadır. Örneğin, çalışma arkadaşlarından doyum ile grup sargınlığ 1 arasındaki korelasyon .65'dir. Benzer bir şekilde, işlemsel adalet ile duygusal bağlılık arasında .41 düzeyinde bir ilişki vardır. Sonradan yapılan analizlerde, aralarında yüksek ilişki olan değişkenlerden bir tanesinin modelden çıkarıldığı durumda, diğeri anlamlı bir etkiye sahip olmaktadır. Örneğin, grup sargınlığı analiz dışında tutularsa, çalışma arkadaşlarından doyum anlamlı bir beta değeri almaktadır. Yordayıcılar arasındaki bu korelasyonun etkisi, aslında yapısal eşitlik modeli kullanılarak kontrol edilmekte ve göreli kuvvetli yordayıcı anlamlı beta değeri almaktadır. Oluşturulan modele bu açıdan yaklaşınca, anlamlı beta değeri alan yordayıcıların, göreli olarak daha önemli olduğu sonucu çıkmaktadır. Birçok bakış açısından çeşitli yordayıcının aynı anda test edildiği çalışma, bu açıdan yapı hakkında daha gerçekçi bir fikir vermektedir.

\section{Kuramsal ve Uygulamaya Yönelik Katkular}

Yukarıda bahsedilen kuramsal etkilerin yanında, elde edilen sonuçların çalışma hayatına yönelik doğurguları da olabilir. Üçlü yapı ve bu yapının öncülleri ile olan ilişkisi hem personel seçme hem de örgütsel davranışların yönetimi açısından bilgiler sağlamaktadır. $\mathrm{Bu}$ bağlamda sargınlık gösterebilecek iş grupları yaratmak kişilerarası destek boyutunda yer alan davranışları olumlu etkilemektedir. Buna ek olarak, beş faktör kişilik modeli içinde yer alan uyumluluk özelliğine sahip çal1şanlar, kişilerarası destek davranışlarını daha fazla sergilemektedir.

Örgüte destek boyutu ile anlamlı ilişkiye sahip olan yordayıcılar duygusal bağlılık, normatif bağlılık ve yöneticiden duyulan doyum boyutlarıdır. Burada önemli bir nokta, daha önce belirtildiği gibi, duygusal ve normatif bağlılık boyutlarının bir arada olmalarına rağmen her ikisinin de anlamlı birer yordayıcı olmasıdır. Duygusal ve normatif bağlılığın ortaya çıkmasını sağlayacak her türlü davranış, örgüte yönelik VP düzeyini artırmak isteyen yöneticilerin dikkate alması gereken davranışlar olacaktır. Yöneticiden duyulan doyum için de benzer bir süreç söz konusudur. Bu araştırma içinde kullanılan ve yöneticiden duyulan doyumu ölçen maddeler değerlendirilecek olursa, çalışanlar, yöneticileri kendilerine adil 
davrandığı ve çalışanların duygularını önemsediği zaman yöneticilerini sevmektedirler. Ayrıca, yöneticinin işini iyi yapan birisi olarak değerlendirilmesi, yöneticinin daha çok sevilmesine sebep olmaktadır.

Coleman ve Borman'ın (2000) modelinin en özgün yanı olan öz-disiplinli inisiyatif boyutunda yer alan davranışlar ile anlamlı ilişkiye sahip yordayıcı değişkenlere göz attığımızda, işin doğasından doyum, işle bütünleşme ve kişilik özelliği olarak öz-disiplinin yordama gücü olduğu görülmektedir. Çalışanın işini daha iyi yapabilmek için gösterdiği VP boyutu olan öz-disiplinli inisiyatifin iși ile daha fazla bütünleșen, yaptığı ișin doğasından doyum elde eden ve öz-disiplini yüksek olan çalışan tarafindan daha fazla yapılmasının ağırlıklı olarak personel seçme açısından önemli doğurguları vardır. Bu üç değişkenden personel seçme aşamasında en kolay ölçülebilecek olanı öz-disiplindir. Diğer iki değişken ise dolaylı yollarla personel seçme sürecinde kullanılabilir. İşi ile bütünleşecek ve işin doğasından doyum sağlayacak çalışanlar, personel seçme sürecinde örgüt ve iş hakkında gerçekçi iş tanımları verilerek örgüte çekilebilir. Gerçekçi olarak verilecek iş tanımları, potansiyel çalışanların kendi kendilerine eleme yapmalarını ve böylece örgütte belirli işleri yapmaktan memnun olacak çalışanlarının işe alınmasını sağlayabilir. Bir başka olasılık ise, personel seçme aşamasında çalışanın özellikleri ile örgütün ve işin özelliklerinin uyumlu olduğu çalışanlara odaklanmaktır. Kişinin, özelliklerine uygun bir işte çalışması, muhtemelen işin doğasından doyum sağlamasını kolaylaştıracaktır.

\section{Kısıtlılıklar ve Gelecek Araștırmalar için Öneriler}

Birçok örgütsel araştırmada ortaya çıkan ortak yöntem varyans1 ve tek kaynaktan veri toplama durumları bu araştırma için de geçerlidir. Bu sebepten ötürü ortaya çıkan ilişkilerin nedensel olduğu söylenemez. Araştırmamızda kullandığımız DFA sonuçları, tek faktörlü yapıların uygun olmadığını göstermektedir ve ortak yöntem varyansının etkisinin sınırlı olabileceği düşünülebilir. Her ne kadar araştırmada ele aldığımız değişkenlerin neredeyse tamamı, çalışandan toplanması daha uygun olan ölçümler olsa da bundan sonraki çalışmalarda tutar1 yanıt verme yanlılığını azaltabilmek için ölçümlerin en azından farklı zamanlarda alınması daha doğru olacaktır.

Araştırmanın üç aşaması da beyaz yakalı olarak nitelenebilecek katılımcılar ile yürütülmüştür. Dolay1sıyla, bu araştırmanın bulguları mavi yakalı çalışanlar için geçerli olmayabilir. VP ölçümleri yazında ağırlıklı olarak çalışanların kendisinden alınmasına rağmen farklı VP değerlendirmelerinin gözlem yapma olanağına sahip farklı kişiler tarafından yapılması ideal olan durumdur. $\mathrm{Bu}$ bağlamda çalışma arkadaşlarına destekle ilgili olan kişilerarası destek boyutunun katılımcının çalışma ar- kadaşlarından ve örgüte destek boyutunun da yöneticiden alınması daha uygun olabilir. Araştırma bağlamında kullanılan grup sargınlığı ölçeği hem kişisel algı hem de grubun bir özelliği olarak düşünülebilir bir kavramdır. $\mathrm{Bu}$ araştırma bağlamında grup sargınlığı bireysel bir değişken olarak ele alınmıştır, ancak grup düzeyi bir ölçümün olanaklı olduğu durumlarda grup sargınlığı kavramının etkisi daha açık bir şekilde görülebilir. Roberts, Chernyshenko, Stark ve Goldberg (2005) tarafindan da belirtildiği gibi, öz-disiplinin tanımlanan alt boyutları heterojen bir yapı göstermektedir ve ilerideki çalışmalarda, araştırmanın konusu ve odaklanmak istediği noktaya göre genel öz-disiplin ölçümü yerine alt özelliklere önem vermek yazına daha çok katkı sağlayacaktır. Benzer bir durum, uyumluluk boyutu için de geçerlidir. Uyumluluğu oluşturan alt özelliklerin, VP ile olan ilişkisinin daha çok araştırılması gerekmektedir. Araştırmada yer alan değişkenlerin, katılımcıların sosyal beğenirlik düzeyinden etkilenme olasılığı mevcuttur. Bu araştırma bağlamında kullanılan ölçeklerdeki birçok madde sosyal beğenirlik açısından yanlılık yaratabilecek potansiyele sahiptir. Çalışanların yaptıkları işi daha zor ve karmaşık gösterme eğilimi ile kendi performansları konusunda abartılı ifadeler kullanma olasılıkları mevcuttur. Son olarak, araştırmada demografik değişkenler ile çalışılan sektörün etkisi incelenmemiştir.

$\mathrm{Bu}$ araştırmanın güçlü yanlarının başında kuramsal bir temele dayanması gelmektedir. Yazında yer alan bilgiler, çok boyutlu kavram modellemeleri çerçevesinde ele alınmış ve alternatif modeller test edilmiştir. Bu araştırma, bilindiği kadarıyla Türkiye'de, VP'yi ele alan ilk araştırmadır ve bu alanda bir ölçek Türkçe alanyazına kazandırılmıştır. Dolayısıyla, bu araştırma, bu konuda daha fazla araştırma yapılmasını kolaylaştırabilecek bir etki gösterebilir. 


\section{Kaynaklar}

Allen, N. J. ve Meyer, J. P. (1990). The measurement and antecedents of affective, continuance and normative commitment to the organization. Journal of Occupational Psychology, 63(1), 1-18. doi:10.1111/j.2044-8325.1990.tb00506.x

Ambrose, M. L. (2002). Contemporary justice research: A new look at familiar questions. Organizational Behavior and Human Decision Processes, 89(1), 803-812. doi:10.1016/S0749-5978(02)00030-4

Bagozzi, R. P. ve Edwards, J. R. (1998). A general approach for representing constructs in organizational research. Organizational Research Methods, 1(1), 45-87. doi:10.1177/109442819800100104

Bagozzi, R. P., Verbeke, W. ve Gavino Jr, J. C. (2003). Culture moderates the self-regulation of shame and its effects on performance: the case of salespersons in The Netherlands and the Philippines. Journal of Applied Psychology, 88(2), 219-233. doi:10.1037/00219010.88.2.219

Bağcı, Z. (2014). Çalışanların iş doyumunun görev ve bağlamsal performanslanı üzerindeki etkisi. Yönetim ve Ekonomi Araştırmaları Dergisi, 12(24), 58-72. doi:10.11611/JMER534

Barrick, M. R. ve Mount, M. K. (1991). The big five personality dimensions and job performance: A meta-analysis. Personnel Psychology, 44(1), 1-26. doi:10.1111/j.1744-6570.1991.tb00688.x

Barrick, M. R., Mount, M. K. ve Judge, T. A. (2001). Personality and performance at the beginning of the new millennium: What do we know and where do we go next?. International Journal of Selection and Assessment, 9(1-2), 9-30. doi:10.1111/14682389.00160 .

Barrick, M. R., Stewart, G. L., Neubert, M. J. ve Mount, M. K. (1998). Relating member ability and personality to work-team processes and team effectiveness. Journal of Applied Psychology, 83(3), 377-391. doi:10.1037/0021-9010.83.3.377

Basım, N. ve Şeşen, H. (2006). Örgütsel vatandaşlık davranış1 ölçeği uyarlama ve karşılaştırma çalışması. Ankara Üniversitesi SBF Dergisi, 61(4), 83-101.

Bass, B. (1965). Organizational psychology. Boston: Allyn \& Bacon.

Bateman, T. S. ve Organ, D. W. (1983). Job satisfaction and the good soldier: The relationship between affect and employee "citizenship". Academy of Management Journal, 26(4), 587-595. doi:10.2307/255908

Benet-Martinez, V. ve John, O. P. (1998). Los cindo grandes across cultures and ethnic groups: Multitrait multimethod analysis of the big five in Spanish and English. Journal of Personality and Social
Psychology, 75(3), 729-750. doi:10.1037/00223514.75.3.729.

Bing, M. N., Davison, H. K., Minor, I., Novicevic, M. M. ve Frink, D. D. (2011). The prediction of task and contextual performance by political skill: A meta-analysis and moderator test. Journal of Vocational Behavior, 79(2), 563-577. doi:10.1016/j. jvb.2011.02.006

Blader, S. L. ve Tyler, T. R. (2009). Testing and extending group engagement model: Linkages between social identity, procedural justice, economic outcomes, and extra role behavior. Journal of Applied Psychology, 94(2), 445-464. doi:10.1037/a0013935

Blau, P. (1964). Exchange and power in social life. New York: Wiley.

Bolino, M. C. ve Turnley, W. H. (2005). The personal costs of citizenship behavior: The relationship between individual initiative and roleoverload, job stress, and work-family conflict. Journal of Applied Psychology, 90(4), 740-748. doi:10.1037/00219010.90.4.740

Bolino, M. C., Turnley, W. H. ve Niehoff, B. P. (2004). The other side of the story: Reexamining prevailing assumptions about organizational citizenship behavior. Human Resources Management Review, 14(2), 229-246. doi:10.1016/j.hrmr.2004.05.004

Borman, W. C., Buck, D. E., Hanson, M. A., Motowidlo, S. J., Stark, S. ve Drasgow, F. (2001). An examination of the comparative reliability, validity, and accuracy of performance ratings made using computerized adaptive rating scales. Journal of Applied Psychology, 86(5), 965-973. doi:10.1037/0021-9010.86.5.965

Borman, W. C. ve Motowidlo, S. C. (1993). Expanding the criterion domain to included elements of contextual performance. N. Schmidt ve W. C. Borman (Eds.), Personnel selection. (71-98). Jossey-Bass Frontiers Series, San Francisco, CA.

Borman, W. C., Motowidlo, S. J., Rose, S. R. ve Hanser, L. M. (1983). Development of a model of soldier effectiveness (Enstitü Rapor Numaras1 95). Minneapolis, MA: Personnel Decisions Research Institutes.

Borman, W. C., Penner, L. A., Allen, T. D. ve Motowidlo, S. J. (2001). Personality predictors of citizenship performance. International Journal of Selection and Assessment, 9(1-2), 52-69. doi:10.1111/14682389.00163

Brief, A. P. ve Motowidlo, S. C. (1986). Prosocial organizational behaviors. Academy of Management Review, 11(4), 710-725. doi:10.5465/amr.1986.4283909

Brown, S. (1996). A meta-analysis and review of organizational research on job involvement. Psychological Bulletin, 120(2), 235-255. doi:10.1037/0033-2909.120.2.235 
Cohen-Charash,Y.veSpector,P.E.(2001). The role of justice in organizations: a meta-analysis. Organizational Behavior and Human Decision Processes, 86(2), 278-321. doi:10.1006/obhd.2001.2958

Coleman, V. I. ve Borman, W. C. (2000). Investigating the underlying structure of citizenship performance domain. Human Resource Management Review, 10(1), 25-44. doi:10.1016/s1053-4822(99)00037-6

Colquitt, J. A. (2001). On the dimensionality of organizational justice: A construct validation of a measure. Journal of Applied Psychology, 86(3), 386400. doi:10.1037/0021-9010.86.3.386

Costa, P. T. ve McCrae, R. R. (1992a). Four ways five factors are basic. Personality and Individual Differences, 13(6), 653-665. doi:10.1016/0191-8869(92)90236-I

Costa, P. T. ve McCrae, R. R. (1992b). Revised NEO Personality Inventory (NEO-PI-R) and NEO FiveFactor (NEO-FFI) Inventory professional manual. Odessa, FL: Psychological Assessment Resources.

Cropanzano, R., Prehar, C. A. ve Chen, P. Y. (2002). Using social exchange theory to distinguish procedural from interactional justice. Group \& Organization Management, 27(3), 324-351. doi:10.1177/1059601102027003002

Çarıkçı, İ., Kanten, S. ve Kanten, P. (2010). Kişilik, duygusal zeka ve örgütsel vatandaşlık davranışları arasındaki ilişkileri belirlemeye yönelik bir araştırma. Süleyman Demirel Üniversitesi Sosyal Bilimler Enstitüsü Dergisi, 11, 41-65.

Dalal, R. S. (2005). A meta-analysis of the relationship between organizational citizenship and counterproductive work behavior. Journal of Applied Psychology, 90(6), 1241-1255. doi:10.1037/00219010.90.6.1241

DeVellis, R. F. (2016). Scale development: Theory and applications. Thousand Oaks, CA: Sage publications.

Diefendorff, J. M., Brown, D. J., Kamin, A. M. ve Lord, R. G. (2002). Examining the roles of job involvement and work centrality in predicting organizational citizenship behaviors and job performance. Journal of Organizational Behavior, 23(1), 93-108. doi:10.1002/job.123

Dobbins, G. H. ve Zaccaro, S. J. (1986). The effects of group cohesion and leader behavior on subordinate satisfaction. Group \& Organization Studies, 11(3), 203-219. doi:10.1177/105960118601100305

Eisenberger, R., Fasolo, P. ve Davis-LaMastro, V. (1990). Perceived organizational support and employee diligence, commitment, and innovation. Journal of Applied Psychology, 75(1), 51-59. doi:10.1037/00219010.75.1.51

Farh, J. L., Podsakoff, P. M. ve Organ, D. W. (1990).
Accounting for organizational citizenship behavior: Leader fairness and task scope versus satisfaction. Journal of Management, 16(4), 705-721. doi:10.1177/014920639001600404

Farh, J. L., Zhong, C. B. ve Organ, D. W. (2004). Organizational citizenship behavior in the People's Republic of China. Organization Science, 15(2), 241253. doi:10.1287/orsc. 1030.0051

Festinger, L. (1950). Informal social communication. Psychological Review, 57(5), 271-282. doi:10.1037/ h0056932

Gaskell, G. (2000). Individual and group interviewing. M. W. Bauer ve G. Gaskell G (Ed.), Qualitative researching: With text, image and sound içinde (s. 3856). London: Sage.

George, J. M. ve Bettenhausen, K. (1990). Understanding prosocial behavior, sales performance, and turnover: A group-level analysis in a service context. Journal of Applied Psychology, 75(6), 698-709. doi:10.1037/0021-9010.75.6.698

George, J. M. ve Brief, A. P. (1992). Feeling good - doing good. A conceptual analysis of the mood at workorganizational spontaneity relationship. Psychological Bulletin, 112(2), 310-329. doi:10.1037/00332909.112.2.310

Giray, M. D. ve Ergin, G. C. (2006). Çift-kariyerli ailelerde bireylerin yaşadıkları iş-aile ve aile-iş çatışmalarının kendini kurgulama davranışı ve yaşam olayları ile ilişkisi. Türk Psikoloji Dergisi, 21, 83-101.

Goldberg, L. R. (1990). An alternative "description of personality": The Big-Five factor structure. Journal of Personality and Social Psychology, 59(6), 12161229. doi:10.1037/0022-3514.59.6.1216

Goldberg, L. R. (1992). The development of markers for the big-five factor structure. Psychological Assessment, 4(1), 26-42. doi:10.1037/1040-3590.4.1.26

Göncü, A., Aycan, Z. ve Johnson, R. E. (2014). Effects of paternalistic and transformational leadership on follower outcomes. The International Journal of Management and Business, 5, 36-58.

Gregersen, H. B. (1993). Multiple commitments at work and extrarole behavior during three stages of organizational tenure. Journal of Business Research, 26(1), 31-47. doi:10.1016/0148-2963(93)90041-M

Güleryüz, E. (2010). Öncülleri ve sonuçları bağlamında örgütsel özdeşimin örgütsel bağlılığın duygusal bağl1lık boyutu ile ilişkisi. Yayınlanmamış doktora tezi, Hacettepe Üniversitesi Sosyal Bilimler Enstitüsü, Ankara.

Güleryüz, E., Giray, D. ve Ceylan, S. (2006). İş konrolü, Örgütsel Özdeşim ve Örgütsel Bağlllık Arasındaki İlişki. Sözel Bildiri, 14. Ulusal Psikoloji Kongresi, Hacettepe Üniversitesi, Ankara. 
Güngör, D. (2016). Psikolojide ölçme araçlarının geliştirilmesi ve uyarlanması kılavuzu. Türk Psikoloji Yazılarl, 19, 104-112.

Gürbüz, S. (2006). Örgütsel vatandaşlık davranışı ile duygusal bağlılık arasındaki ilişkilerin belirlenmesine yönelik bir araştırma. Ekonomik ve Sosyal Araştırmalar Dergisi, 3(1), 48-75.

Hackett, R. D., Farh, J. L., Song, L. J. ve Lapierre, L. M. (2003). LMX and organizational citizenship behavior: Examining links within and across Western and Chinese samples. G. B. Graen (Ed.), LMX leadership: The series (Cilt 1) (219-264). Greenwich, CT: Information Age Publishing.

Hackman, J. R. ve Lawler E. E. (1971). Employee reactions to job characteristics. Journal of Applied Psychology, 55(3), 259-286. doi:10.1037/h0031152

Hoffman, B. J., Blair, C. A., Meriac, J. P. ve Woehr, D. J. (2007). Expanding the criterion domain? A quantitative review of the OCB literature. Journal of Applied Psychology, 92(2), 555-566. doi:10.1037/0021-9010.92.2.555

Hough, L. M., Eaton, N. K., Dunnette, M. D., Kamp, J. D. ve McCloy, R. A. (1990). Criterion-related validities of personality constructs and the effect of reponse distortion on those validities. Journal of Applied Psychology, 75(5), 581-595. doi:10.1037/00219010.75.5.581

Hu, L., ve Bentler, P. M. (1999). Cutoff criteria for fit indexes in covariance structure analysis: Conventional criteria versus new alternatives. Structural Equation Modeling, 6(1), 1-55. doi:10.1080/10705519909540118

Hurtz, G. M. ve Donovan, J. J. (2000). Personality and job performance: The big-five revisited. Journal of Applied Psychology, 85(4), 869-879. doi:10.1037/ a0013329

Ilies, R., Fulmer, I. S., Spitzmuller, M. ve Johnson, M. D. (2009). Personality and citizenship behavior: The mediating role of job satisfaction. Journal of Applied Psychology, 94(4), 945-959. doi:10.1037/ a0013329

Ilies, R., Nahrgang, J. D. ve Morgeson, F. P. (2007). Leader-member exchange and citizenship behaviors: A meta-analysis. Journal of Applied Psychology, 92(1), 269-277. doi:10.1037/0021-9010.92.1.269

Jaros, S. J. (1997). An assessment of Meyer and Allen's (1991) three-component model of organizational commitment and turnover intentions. Journal of Vocational Behavior, 51(3), 319-337. doi:10.1006/ jvbe.1995.1553

Jöreskog, K. G. ve Sörbom, D. (2003). LISREL 8.54 [Computer Software]. Lincolnwood, IL: Scientific Software International, Inc.
Judge, T. A., Thoresen, C. J., Bono, J. E., ve Patton, G. K. (2001). The job satisfaction-job performance relationship: A qualitative and quantitative review. Psychological Bulletin, 127(3), 376-407. doi:10.1037/0033-2909.127.3.376

Kahn, W. A. (1990). Psychological conditions of personal engagement and disengagement at work. Academy of Management Journal, 33(4), 692-724. doi: $10.5465 / 256287$

Kamdar, D. ve Van Dyne, L. (2007). The joint effects of personality and workplace social exchange relationships in predicting task performance and citizenship performance. Journal of Applied Psychology, 92(5), 1286-1298. doi:10.1037/00219010.92.5.1286

Kanungo, R. N. (1982). Measurement of job and work involvement. Journal of Applied Psychology, 67(3), 341-349. doi:10.1037/0021-9010.67.3.341

Karabay, E. Z. (2004). Kamuda ve özel sektörde örgütsel adalet algısı ile örgütsel bağlllık arasındaki ilişkiler. Yayınlanmamıș yüksek lisans tezi, Hacettepe Üniversitesi Sosyal Bilimler Enstitüsü, Ankara.

Karakurum, M. (2005). The effects of person-organization fit on employee job satisfaction, performance and organizational commitment in a Turkish public organization. Yayınlanmamış yüksek lisans tezi, Orta Doğu Teknik Üniversitesi, Ankara.

Katz, D. ve Kahn, R. L. (1978). The social psychology of organizations, (2nd edn.). New York: Wiley.

Kidwell Jr, R. E., Mossholder, K. W. ve Bennett, N. (1997). Cohesiveness and organizational citizenship behavior: A multilevel analysis using work groups and individuals. Journal of Management, 23(6), 775793. doi:10.1177/014920639702300605

Kline, R. B. (2015). Principles and practice of structural equation modeling (2. bask1). Guilford publications.

Ko, J. W., Price, J. L. ve Mueller, C.W. (1997). Assessment of Meyer and Allen's three-component model of organizational commitment in South Korea. Journal of Applied Psychology, 82(6), 961-973. doi:10.1037/0021-9010.82.6.961

Konovsky, M.A. vePugh, S. D. (1994). Citizenship behavior and social exchange. Academy of Management Journal, 37(3), 656-669. doi:10.5465/256704

Lavelle, J. J., Rupp, D. E. ve Brockner, J. (2007). Taking a multifoci approach to the study of justice, social exchange, and organizational citizenship behavior: The target similarity model. Journal of Management, 33(6), 841-866. doi:10.1177/0149206307307635

Law, K. S., Wong, C. S. ve Mobley, W. H. (1998). Toward a taxonomy of multidimensional constructs. Academy of Management Review, 23(4), 741-755. doi:10.5465/ amr.1998.1255636 
Law, K. S., Wong, C. S., Huang, G. H., ve Li, X. (2008) The effects of emotional intelligence on job performance and life satisfaction for the research and development scientists in China. Asia Pacific Journal of Management, 25(1), 51-69. doi:10.1007/s10490007-9062-3

Lawler, E. E., III. (1986). High involvement management. San Francisco: Jossey-Bass.

Le, H., Schmidt, F. L., Harter, J. K. ve Lauver, K. J. (2010). The problem of empirical redundancy of constructs in organizational research: An empirical investigation. Organizational Behavior and Human Decision Processes, 112(2), 112-125. doi:10.1016/j. obhdp.2010.02.003

Lee, K., Allen, N. J., Meyer, J.P. ve Rhee, K.Y. (2001). The three-component model of organisational commitment: An application to South Korea. Applied Psychology: An International Review, 50(4), 596-614. doi:10.1111/1464-0597.00075

LePine, J. A., Erez, A. ve Johnson, D. E. (2002). The nature and dimensionality of organizational citizenship behavior: A critical review and meta-analysis. Journal of Applied Psychology, 87(1), 52-65. doi:10.1037//0021-9010.87.1.52

LePine, J. A. ve Van Dyne, L. (2001). Voice and cooperative behavior as contrasting forms of contextual performance: Evidence of differential relationships with Big Five personality characteristics and cognitive ability. Journal of Applied Psychology, 86(2), 326336. doi:10.1037/0021-9010.86.2.326

Lind, E. A. ve Tyler, T. R. (1988). The social psychology of procedural justice. New York: Plenum Press.

MacCallum, R. C., Browne, M. W. ve Sugawara, H. M. (1996). Power analysis and determination of sample size for covariance structure modeling. Psychological Methods, 1(2), 130-149. doi:10.1037/1082989X.1.2.130

MacKenzie, S. B., Podsakoff, P. M. ve Ahearne, M. (1998). Some possible antecedents and consequences of in-role and extra-role salesperson performance. Journal of Marketing, 62(3), 87-98. doi:10.1177/002224299806200306

MacKenzie, S. B., Podsakoff, P. M., ve Podsakoff, N. P. (2011). Construct measurement and validation procedures in MIS and behavioral research: Integrating new and existing techniques. MIS Quarterly, 35(2), 293-334. doi:10.2307/23044045

Meyer, J. P. ve Allen, N. J. (1984). Testing the "sidebet theory" of organizational commitment: Some methodological considerations. Journal of Applied Psychology, 69(3), 372-378. doi:10.1037/00219010.69.3.372

Meyer, J. P., Allen, N. J. ve Smith, C. A. (1993). Commitment to organizations and occupations: Extension and test of a three-component conceptualization. Journal of Applied Psychology, 78(4), 538-551. doi:10.1037/0021-9010.78.4.538

Meyer, J. P., Stanley, D. J., Herscovitch, L. ve Topolnytsky, L. (2002). Affective, continuance, and normative commitment to the organization: A meta-analysis of antecedents, correlates, and consequences. Journal of Vocational Behavior, 61(1), 20-52. doi:10.1006/ jvbe. 2001.1842

Miao, C., Humphrey, R. H. ve Qian, S. (2017). Are the emotionally intelligent good citizens or counterproductive? A meta-analysis of emotional intelligence and its relationships with organizational citizenship behavior and counterproductive work behavior. Personality and Individual Differences, 116(1), 144-156. doi:10.1016/j.paid.2017.04.015

Miao, C., Humphrey, R. H. ve Qian, S. (2018). A crosscultural meta-analysis of how leader emotional intelligence influences subordinate task performance and organizational citizenship behavior. Journal of World Business, 53(4), 463-474. doi:10.1016/j. jwb.2018.01.003

Miller, R. L., Griffin, M. A. ve Hart, P. M. (1999). Personality and organizational health: The role of conscientiousness. Work and Stress, 13(1), 7-19. doi:10.1080/026783799296156

Misumi, J.ve Yamori, K. (1991). Values and beyond: Training for a higher work centrality in Japan. European Journal of Work and Organizational Psychology, 1(2/3), 135-145. doi:10.1080/09602009108408518

Moorman, R. H. (1991). Relationship between organizational justice and organizational citizenship behaviors: Do fairness perceptions infuence employee citizenship? Journal of Applied Psychology, 76(6), 845-855. doi:10.1037/0021-9010.76.6.845

Morrison, E. W. (1994). Role definitions and organizational citizenship behavior: The importance of the employee's perspective. Academy of Management, 37(6), 1543-1567. doi:10.5465/256798

Motowidlo, S. J. (2000). Some basic issues related to contextual performance and organizational citizenship behavior in human resources management. Human Resource Management Review, 10(1), 115-126. doi:10.1016/S1053-4822(99)00042-X

Motowidlo, S. J. (2003). Job performance. W. C. Borman, R. J. Ilgen ve J. Klimoski (Ed.), Handbook of psychology volume 12: Industrial and organizational psychology (s. 39-53). New Jersey: John Wiley ve Sons. Inc.

Motowidlo, S. J. ve Van Scotter, J. R. (1994). Evidence that task performance should be distinguished from contextual performance. Journal of Applied Psychology, 79(4), 475-480. doi:10.1037/0021-9010.79.4.475 
Mount, M. K., Barrick, M. R. ve Stewart, G. L. (1998). Five-factor model of personality and performance in jobs involving interpersonal interactions. Human Performance, 11(2-3), 145-165. doi:10.1080/089592 85.1998.9668029

MOW International Research Team. (1987). The meaning of work. Orlando, FL: Academic Press.

Mowday, R. T., Porter, L. W. ve Steers, R. M. (1982). Employee-organization linkages. New York: Academic Press.

Mowday, R. T., Steers, R. M. ve Porter, L.W. (1979). The measurement of organizational commitment. Journal of Vocational Behavior, 14(2), 224-247. doi:10.1016/0001-8791(79)90072-1

Netemeyer, R. G., Boles, J. S. ve McMurrian, R. (1996). Development and validation of work-family conflict and family-work conflict scales. Journal of Applied Psychology, 81(4), 400-410. doi:10.1037/00219010.81.4.400

Neuman, G. A. ve Kickul, J. R. (1998). Organizational citizenship behaviors: Achievement orientation and personality. Journal of Business and Psychology, 13(2), 263-279. doi:10.1023/A:1022963108025

Niehoff, B. P. ve Moorman, R. H. (1993). Justice as a mediator of the relationship between methods of monitoring and organizational citizenship behavior. Academy of Management Journal, 36(3), 527-556. doi: $10.5465 / 256591$

O'Reilly, C. ve Chatman, J. (1986). Organizational commitmentandpsychologicalattachment:Theeffects of compliance, identification, and internalization on prosocial behavior. Journal of Applied Psychology, 71(3), 492-499. doi:10.1037/0021-9010.71.3.492

Ok, A. B. (2007). Correlates of organizational commitment: A special emphasis on organizational communication. Yayınlanmamış yüksek lisans tezi, Orta Doğu Teknik Üniversitesi Sosyal Bilimler Enstitüsü, Ankara.

Olkkonen, M. E ve Lipponen J. (2006). Relationships between organizational justice, identification with organization and work unit, and group-related outcomes. Organizational Behavior and Human Decision Processes, 100(2), 202-215. doi:10.1016/j. obhdp.2005.08.007

Ones, D. S., Viswesvaran, C. ve Schmidt, F. L. (1993). Comprehensive meta-analysis of integrity test validities: Findings and implications for personnel selection and theories of job performance. Journal of Applied Psychology, 78(4), 679-703. doi:10.1037/0021-9010.78.4.679

Organ, D. W. (1977). A reappraisal and reinterpretation of the satisfaction-causes-performance hypothesis. Academy of Management Review, 2(1), 46-53. doi:10.5465/amr.1977.4409162
Organ, D. W. (1988). Organizational citizenship behavior: The good soldier syndrome. Lexington, MA: Lexington Books.

Organ, D. W. (1990). The motivational basis of organizational citizenship behavior. B. M. Staw ve L. L. Cummings (Ed.), Research in organizational behavior, Vol. 12 içinde (s. 43-72). Greenwich, CT: JAI Press.

Organ, D. W. (1994). Personality and organizational citizenship behavior. Journal of Management, 20(2), 465-478. doi:10.1177/014920639402000208

Organ, D. W. (1997). Organizational citizenship behavior: It's construct clean-up time. Human Performance, 10(2), 85-97. doi:10.1207/s15327043hup1002_2

Organ, D. W. ve Konovsky, M. (1989). Cognitive versus affective determinants of organizational citizenship behavior. Journal of Applied Psychology, 74(1), 157164. doi:10.1037/0021-9010.74.1.157

Organ, D. W. ve Ryan, K. (1995). A meta-analytical review of attitudinal and dispositional predictors of organizational citizenship behavior. Personnel Psychology, 48(4), 775-802. doi:10.1111/j.1744-6570.1995.tb01781.x

Özen-İşbaşı, J. (2000). Çalışanların yöneticilerine duydukları güvenin ve örgütsel adalete ilişkin algılamalarının örgütsel vatandaşlık davranışlarının oluşumundaki rolü: Bir turizm örgütünde uygulama. Yayınlanmamış yüksek lisans tezi, Akdeniz Üniversitesi Sosyal Bilimler Enstitüsü, Antalya.

Paine, J. B. ve Organ, D. W. (2000). The cultural matrix of organizational citizenship behavior: Some preliminary conceptual and emprical observations. Human Resource Management Review, 10(1), 45-59. doi:10.1016/S1053-4822(99)00038-8

Podsakoff, P. M., MacKenzie, S. B. ve Bommer, W. H. (1996). Transformational leader behaviors and substitutes for leadership as determinants of employee satisfaction, commitment, trust, and organizational citizenship behaviors. Journal of Management, 22(2), 259-298. doi:10.1177/014920639602200204

Podsakoff, P. M., MacKenzie, S. B., Moorman, R. H. ve Fetter, R. (1990). Transformational leader behaviors and their effects of followers' trust in leader, satisfaction, and organizational citizenship behavior. Leadership Quarterly, 1(2), 107-142. doi:10.1016/1048-9843(90)90009-7

Podsakoff, P. M., MacKenzie, S. B., Paine, J. B. ve Bachrach, D. G. (2000). Organizational citizenship behaviors: A critical review of the theoretical and emprical literature and suggestions for future research. Journal of Management, 26(3), 513-563. doi: $10.1177 / 014920630002600307$ 
Podsakoff, N. P., Whiting, S. W., Podsakoff, P. M. ve Blume, B. D. (2009). Individual and organizational level consequences of organizational citizenship behaviors: A meta-analysis. Journal of Applied Psychology, 94(1), 122-141. doi:10.1037/a0013079

Polat, S. ve Celep, C. (2008). Ortaöğretim öğretmenlerinin örgütsel adalet, örgütsel güven, örgütsel vatandaşlık davranışlarına ilişkin algıları. Kuram ve Uygulamada Ĕ̌itim Yönetimi Dergisi, 14(2), 307-331.

Roberts, B. W., Chernyshenko, O. S., Stark, S. ve Goldberg, L. R. (2005). The structure of conscientiousness: An empirical investigation based on seven major personality questionnaires. Personnel Psychology, 58(1), 103-139. doi:10.1111/j.17446570.2005.00301.x

Rupp, D. E. ve Cropanzano, R. (2002). The mediating effects of social exchange relationships in predicting workplace outcomes from multifoci organizational justice. Organizational Behavior and Human Decision Processes, 89(1), 925-946. doi:10.1016/ S0749-5978(02)00036-5

Ryan, R. M. ve Deci, E. L. (2000). Self-determination theory and the facilitation of intrinsic motivation, social development, and well-being. American Psychologist, 55(1), 68-78. doi:10.1037/0003066X.55.1.68

Salgado, J. F. (1997). The five factor model of personality and job performance in the European Community. Journal of Applied Psychology, 82(1), 30-43. doi:10.1037/0021-9010.82.1.30

Schachter, S., Ellertson, N., McBride, D. ve Gregory, D. (1951). An experimental study of cohesiveness and productivity. Human Relations, 4, 229-238. doi:10.1177/001872675100400303

Schmitt, D. P., Alcalay, L., Allik, J., Ault, L., Austers, I., Bennett, K. L. ve ark. (2003). Universal sex differences in the desire for sexual variety: Tests from 52 nations, 6 continents, and 13 islands. Journal of Personality and Social Psychology, 85(1), 85-104. doi:10.1037/0022-3514.85.1.85

Schnake, M., Dumler, M. P. ve Cochran, D. S. (1993). The relationship between "traditional" leadership, "super" leadership, and organizational citizenship behavior. Group and Organization Management, 18(3), 352365. doi:10.1177/1059601193183006

Schneider, R. J., Goff, M., Anderson, S. ve Borman, W. C. (2003). Computerized adaptive rating scales for measuring managerial performance. International Journal of Selection and Assessment, 11(2-3), 237246. doi:10.1111/1468-2389.00247

Shaffer, J. A., DeGeest, D. ve Li, A. (2016). Tackling the problem of construct proliferation: A guide to assessing the discriminant validity of conceptually related constructs. Organizational Research Methods, 19(1), 80-110. doi:10.1177/1094428115598239

Smith, C. A., Organ, D. W. ve Near, J. P. (1983). Organizational citizenship behavior: Its nature and antecedents. Journal of Applied Psychology, 68(4), 653-663. doi:10.1037/0021-9010.68.4.653

Spector, P. E. (1997). Job satisfaction: Application, assessment, causes, and consequences. Thousand Oaks, CA: Sage.

Sümer, N. ve Sümer, H. C. (2003). Turkish translation and adaptation of the BFI. Unpublished manuscript, Middle East Technical University. Ankara, Turkey.

Şeşen, H. ve Basım, H. N. (2010). Çalışanların adalet algısının örgütsel vatandaşlık davranışlarına etkisi: İş tatmininin aracılık rolü. ODTÜ Gelişme Dergisi, 37, 171-193.

Takleab, A. G., Takeuchi, R. ve Taylor, M. S. (2005). Extending the chain of relationships among organizational justice, social exchange, and employee reactions: The role of contract violations. Academy of Management Journal, 48(1), 146-157. doi:10.5465/ amj.2005.15993162

Tay, L. ve Drasgow, F. (2012). Theoretical, statistical, and substantive issues in the assessment of construct dimensionality: Accounting for the item response process. Organizational Research Methods, 15(3), 363-384. doi:10.1177/1094428112439709

Tett, R. P., Jackson, D. N., Rothstein, M. R. ve Reddon, J. R. (1994). Meta-analysis of personality-job performance relations: A reply to Ones, Mount, Barrick, and Hunter (1994). Personnel Psychology, 47(1), 157-172. doi:10.1111/j.1744-6570.1994. tb02415.x

Thibaut, J. W. ve Kelley, H. H. (1959). The Social Psychology of Groups. New York; Wiley.

Van Dyne, L. V., Graham, J. M. ve Dienesch, R. M. (1994). Organizational citizenship behavior: Construct redefinition, measurement, and validation. Academy of Management Journal, 37(4), 765-802. doi: $10.5465 / 256600$

Van Scotter, J. R. ve Motowidlo, S. J. (1996). Interpersonal facilitation and job dedication as separate facets of contextual performance. Journal of Applied Psychology, 81(5), 525-531. doi:10.1037/00219010.81.5.525

Viswesvaran, C. ve Ones, D. S. (2000). Perspectives on models of job performance. International Journal of Selection and Assessment, 8(4), 216-226. doi:10.1111/1468-2389.00151

Walsh, J. P., Ashford, S. J. ve Hill, T. E. (1985). Feedback obstruction: The influence of the information environment on employee turnover intentions. Human Relations, 38(1), 23-46. doi:10.1177/001872678503800102 
Wasti, S. A. (2003). The influence of cultural values on antecedents of organizational commitment: An individual-level analysis. Applied Psychology: An International Review, 52(4), 533-554. doi:10.1111/1464-0597.00150

Wasti, S. A. (2005). Commitment profiles: Combinations of organizational commitment forms and job outcomes. Journal of Vocational Behavior, 67(2), 290-308. doi:10.1016/j.jvb.2004.07.002

Weiner, Y. ve Vardi, Y. (1980). Relationships between job, organization, and career commitments and work outcomes: An integrated approach. Organizational Behavior and Human Decision Processes, 26(1), 8196. doi:10.1016/0030-5073(80)90048-3

Williams, L. J. ve Anderson, S. E. (1991). Job satisfaction and organizational commitment as predictors of organizational citizenship and in-role behaviors. Journal of Management, 17(3), 601-617. doi:10.1177/014920639101700305

Wong, C. S., Law, K. S. ve Huang, G. (2008). On the importance of construct-level analysis for multidimensional constructs in theory development and testing. Journal of Management, 34(4), 744-764. doi:10.1177/0149206307312506

Yelboğa, A. (2009). Validity and reliability of the Turkish version of the job satisfaction survey. World Applied Sciences Journal, 6(8), 1066-1072. 
Ek. Vatandaşlık Performansı Ölçeği

\section{Vatandaşlık Performansı Ölçeği}

Diğer çalışanlara öneriler sunarak yardım etmek

Diğer çalışanlara önemli bilgileri sunmak ve becerileri kazandırmak

Başkalarına ait bazı görevleri gerektiğinde (örneğin o kişi işe gelmediği zaman) inisiyatif alarak yerine getirmek

Kişisel sorunları olan çalışanlara duygusal destek sağlamak

Diğer çalışanlara bilmeleri gereken olaylar hakkında bilgi vermek

Takım hedeflerini kişisel hedeflerin önünde tutmak

Diğer çalışanlar ile ilişkilerde nazik olmak ve diğerlerini güdülemek

Kurumu koruyarak ve geliştirerek dişarıya karşı savunmak

Geçici zorluklar yaşansa bile kurumda çalışmaya devam ederek sadakat göstermek

Kurumun amaçlarını ve hedeflerini desteklemek

Kurumun kurallarına uymak ve öneriler getirmek

Zor koşullara rağmen ekstra çaba göstererek sebat etmek

Kendi görevi olmamasına rağmen hedeflere ulaşılması için inisiyatif alarak bazı işleri üstlenmek

Bütün görevlerini yerine getirse bile daha verimli olabilmek için ek görevler bulmak

Bilgi ve yeteneklerini geliştirmek için, kendi zamanı ve kaynaklarını kullanarak, kurum içinde veya dışında ortaya çıkan firsatları değerlendirmek

\section{Boyut}

Kişilerarası Destek

Kişilerarası Destek

Kişilerarası Destek

Kişilerarası Destek

Kişilerarası Destek

Kişilerarası Destek

Kişilerarası Destek

Örgüte Destek

Örgüte Destek

Örgüte Destek

Örgüte Destek

Öz-disiplinli İnisiyatif

Öz-disiplinli İnisiyatif

Öz-disiplinli İnisiyatif

Öz-disiplinli İnisiyatif 


\section{Summary \\ Construct Validity and Predictors of Three-Dimensional Citizenship Performance in Turkey}

\author{
Savaş Ceylan \\ Hacettepe University
}

After the first efforts to define citizenship behaviors (Bateman \& Organ, 1983; Organ, 1977), the concept has received a great deal of attention from organizational scholars. Scholars have investigated the relationships between citizenship behaviors and more than 200 different variables (LePine, Erez, \& Johnson, 2002). This descriptive information can be interpreted positively, as researchers applied different points of view to studying citizenship behaviors. However, it can also be interpreted negatively, as the number of studies questioning the underlying assumptions of citizenship behaviors is limited and there are controversies about its dimensionality and its overlap with related concepts (Bolino, Turnley, \& Neihoff, 2004). Nearly 30 types of citizenship behaviors have been identified (Coleman \& Borman, 2000; Podsakoff, MazKenzie, Paine, \& Bachrach, 2000) and the content overlap of these dimensions contaminates the citizenship literature. Specifically, given the similarities of organizational citizenship behaviors (OCB; Smith, Organ, \& Near, 1983) with contextual performance (Borman \& Motowidlo, 1993), prosocial organizational behavior (Brief \& Motowidlo, 1986), soldier effectiveness (Borman, Motowidlo, Rose, \& Hanser, 1983), and organizational spontaneity (George \& Brief, 1992), it is difficult to create cumulative knowledge (Le, Schmidt, Harter, \& Lauver, 2010).

However, there are also a number of important theoretical and empirical studies conducted to solve this problem. For example, Organ (1997) offered a reconceptualization of OCB and used the term citizenship performance $(\mathrm{CP})$ to define all related concepts. In an effort to delineate the CP construct, Coleman and Borman (2000) generated similarity data through inductive content sorting of $27 \mathrm{CP}$ behaviors defined in the literature (e.g., Borman \& Motowidlo, 1993; Brief \& Motowidlo, 1986; George \& Brief, 1992; Organ, 1988; Smith et al., 1983; Van Dyne, Graham, \& Dienesch, 1994; Williams \& Anderson, 1991). The content

\author{
Canan Ergin \\ Özyeğin University
}

sorters were members of the Society for Industrial and Organizational Psychology (SIOP). Similarity index was used in the analysis and the results suggested that CP could be organized in three broad categories of behaviors. Later, Borman, Buck et al. (2001) reported that 2300 contextual performance examples were successfully sorted into these three dimensions, indicating the validity of the three-dimensional model of interpersonal citizenship performance (ICP), organizational citizenship performance (OCP), and conscientious initiative (CI).

ICP includes behaviors benefiting other organizational members, OCP includes behaviors benefiting the organization, and finally, CI includes behaviors benefiting the job or the task. This model is parsimonious, compared to the other models of OCB (i.e., altruism, courtesy, sportsmanship, civic virtue, and conscientiousness), and yet comprehensive. By including CI, CP extends Williams and Anderson's OCB toward individuals (OCB-I) and OCB toward the organization (OCB-O). Coleman and Borman (2000) stated that CI splitted the job dedication dimension of contextual performance (Van Scotter \& Motowidlo, 1996) and extended the domain of contextual performance.

Although various OCB and contextual performance scales have been translated into Turkish (e.g., Basim \& Şeşen; Göncü, Aycan, \& Johnson, 2014; Karakurum, 2005), no research has yet investigated the validity of the CP model in Turkey. Therefore, to investigate the construct validity of $\mathrm{CP}$ in Turkey, three studies were conducted. First, the face validity of the CP construct was examined via semi-structured interviews. Second, the factor structure, discriminant validity, and internal consistency of CP were examined. Third, the relationships of CP dimensions with various job attitudes and personality traits from the perspectives of the target similarity model, social exchange theory, and intrinsic motivation were investigated. 


\section{Study 1: Face and Content Validity of Citizenship Performance in Turkey}

\begin{abstract}
Method
Participants and Procedure. We conducted 10 semi-structured interviews with employees from different types of organizations. Three participants were working for public organizations, and seven were working for private companies. Mean age was 37.3 ( $S D$ $=9.71$ ). Organizational tenure of the participants ranged from one year to 35 years $(M=11.15, S D=10.04)$. Heterogeneity of the sample was assured by choosing participants from different sectors (e.g., construction, human resources, information technology, academics, engineering). Interviews were conducted by the first author and lasted 55-90 minutes. All interviews were tape-recorded with the permission of the participants, and participants were assured of confidentiality.
\end{abstract}

\section{Study Protocol and Results}

At the beginning of the interview, participants were given the definitions of task performance and $\mathrm{CP}$ put forth by Motowidlo (2003). They were asked to indicate if the definitions made sense to them and to report work incidents that can be defined as task and/or CP according to the definition given. Then, the 15 items of the $\mathrm{CP}$ scale (Borman, Buck et al., 2001) were read to the participants without mentioning what the scale measured, and they were asked to report the incidents that they themselves or their co-workers had experienced. Then, the participants were told that the items were from a CP scale, and they were asked to offer items to better measure the concept according to the definition. Three independent judges coded all responses. Results showed that all participants successfully reported $\mathrm{CP}$ work incidents and none of the participants offered any additional item to the scale. Thus, we decided to continue without changing any items of the CP scale. The results of Study 1 supported the face validity of the CP scale in Turkey.

\section{Study 2 -Reliability and Validity of Citizenship Performance in Turkey}

The aim of the second study was to investigate the factorial structure, discriminant validity, and reliability of the CP scale. Based on previous OCB and contextual performance literature (e.g., Bolino \& Turnley, 2005; Diefendorff, Brown, Kamin, \& Lord, 2002; Kidwell, Mossholder, \& Bennett, 1997; LePine et al., 2001), we expected CP to have positive relationships with job satisfaction, job involvement, work-family conflict, and importance of work; negative relationships with importance of leisure and intention to quit; and finally nonsignificant relationships with importance of community, religion, and family.

\section{Method}

Participants and Procedure. The sample included 213 (104 women and 107 men) employees from four different cities of Turkey. Of the participants, 132 were employed in public sector and 77 were employed in private companies. Mean age was 33.32 years $(S D=$ $6.90)$ and mean tenure was 10.40 years $(S D=7.15)$. Of the participants, $40 \%$ had at least a college degree.

\section{Measures}

Citizenship Performance. The same scale used in Study 1 was used to collect data. The scale consisted of 15 items rated on a 5-point Likert-type scale $(1=$ Never, 5 = Very Often). Interpersonal support was measured with seven items, and organizational support and conscientious initiative were each measured with four items, with Cronbach alpha values of $.86, .80$, and .85 , respectively.

Job Satisfaction Scale. The Job Satisfaction Survey (JSS; Spector, 1997) was used to measure satisfaction of participants. The scale consisted of 36 items measuring nine dimensions, with four items per dimension. Items were rated on a 5 -point scale $(1=$ Strongly Disagree, $5=$ Strongly Agree). The dimensions of the scale were pay, promotion, supervision, fringe benefits, contingent rewards, operating procedures, coworkers, nature of work, and communication. The scale was adapted to Turkish by Yelboğa (2009), and Cronbach alpha values ranged between .63 and .88 . In addition to the JSS, we also asked participants, "In general, how satisfied are you with your job?".

Job Involvement Scale. This 10-item scale was developed by Kanungo (1982) and translated into Turkish for the current study. Items were rated on a 5-point scale $(1=$ Strongly Disagree, $5=$ Strongly Agree). Cronbach alpha coefficient was .90 .

Group Cohesiveness. Group cohesiveness was measured by eight items developed by Dobbins and Zaccaro (1986) and revised by Kidwell et al. (1997). The scale was translated into Turkish for the current study. Items were rated on a 5 -point scale $(1=$ Strongly Disagree, $5=$ Strongly Agree). Cronbach alpha coefficient was .87 .

Work-Family and Family-Work Conflict Scale. The scale was developed by Netemeyer, Boles, and McMurrian (1996) and adapted to Turkish by Giray and Ergin (2006). Each facet was measured by five items and items were rated on a 5-point scale $(1=$ Strongly Disagree, $5=$ Strongly Agree). Cronbach alpha coefficient was .90 for both facets. 
Centrality of Work Question. Centrality of work measure (MOW, International Research Team, 1987) included a single question and participants were asked to distribute 100 points across five aspects of their lives, namely, leisure, work, community, religion, and family.

Turnover Intentions. Turnover intentions were assessed with the scale developed by Walsh, Ashford, and Hill (1985). The scale was revised and adapted to Turkish by Ok (2007). Items were rated on a 5-point scale $(1=$ Strongly Disagree, $5=$ Strongly Agree $)$. Cronbach alpha coefficient was .90 .

\section{Results and Discussion}

Confirmatory factor analysis (CFA) was conducted with LISREL 8.54 (Jöreskog \& Sörbom, 2003). Three items from the JSS and two items from the job involvement scale were deleted due to nonsignificant paths. All other items loaded on their respective factors. CFA results produced an acceptable fit to the data $(\chi 2(146)=330.0$, $p<.001, \mathrm{CFI}=.95$, TLI $=.94$, RMSEA $=.045)$. The correlations among CP dimensions ranged between .48 and $.61(p<.01)$. As expected, CP dimensions positively correlated with job satisfaction, group cohesiveness, job involvement, and work-family conflict $(r=.15-.30, p<$ $.05)$. The relationship between OCP and intention to quit was negative $(r=-.20, p<.01)$. The relationship between $\mathrm{CP}$ and family-work conflict was nonsignificant. Lastly, $\mathrm{CP}$ was positively related with importance of work $(r=$ $.18, p<.05)$ and negatively related with importance of leisure $(r=-.13, p<.05)$. The Cronbach alpha coefficients of $\mathrm{CP}$ dimensions ranged between .78 and .85. Therefore, we concluded that the $\mathrm{CP}$ scale showed adequate initial validity and reliability evidence.

\section{Study 3 - Predictors and Construct Validity of CP}

Study 3 was designed to assess different alternative factor structures of $\mathrm{CP}$ based on the discussions regarding multidimensional constructs in organizational psychology (e.g., Law et al., 1998). Specifically, we tested three models of CP: one-, two-, and threefactor models. One-factor model assumes that $\mathrm{CP}$ is a unidimensional latent factor. Two-factor model includes Williams and Anderson's (1991) OCB-I and OCB-O dimensions. We aimed to compare the three-factor solution with these alternatives to investigate further validity of the $\mathrm{CP}$ model.

In addition, based on social exchange, target similarity, and intrinsic motivation perspectives, we proposed a model of different predictors of the $\mathrm{CP}$ dimensions. The model includes satisfaction with co-workers, group cohesiveness, and agreeableness as predictors of interpersonal citizenship; affective commitment, normative commitment, procedural justice, and satisfaction with supervisor as predictors of organizational citizenship, and finally satisfaction with nature of work, job involvement and conscientiousness as predictors of conscientious initiative.

\section{Method}

Participants and Procedure. A total of 619 responses were collected (269 women, $345 \mathrm{men}$ ). Of the participants, 322 were employed in public sector and 285 were employed in private companies. Participants' mean age was $34.47(S D=9.26)$. Forty percent had at least a college degree.

Measures. In addition to the scales (citizenship performance; satisfaction with nature of work, supervisor, and coworkers; job involvement; group cohesiveness) used in Study 2, procedural justice, affective and normative commitment, conscientiousness, and agreeableness scales were used to collect data in Study 3.

Procedural Justice. We used four items measuring procedural justice from Colquitt's (2001) organizational justice scale. The scale was adapted to Turkish by Karabay (2004). The items were rated on a 5-point Likert scale $(1=$ Strongly disagree, $5=$ Strongly agree $)$, and Cronbach alpha coefficient was 89 .

Affective and Normative Organizational Commitment. We used eight and ten items of the Organizational Commitment Scale developed by Allen and Meyer (1990) to measure affective and normative commitment, respectively. The scale was adapted to Turkish and validated by Wasti (2003). Cronbach alpha coefficients were .83 and .87 , respectively.

Conscientiousness and Agreeableness. We measured conscientiousness with nine and agreeableness with nine items of the Big Five Inventory (BFI; BenetMartines \& John, 1998). Schmitt et al. (2004) reported that BFI was a valid measure in different cultural settings. BFI was translated into Turkish and validated by Sümer and Sümer (2003) as part of Schmitt et al.'s (2003) study. Cronbach alpha coefficients were .77 and .64 , respectively.

Statistical Strategy. As one of the aims of the current study was to compare alternative conceptualizations of $\mathrm{CP}$, we compared three-dimensional, two-dimensional, and one-dimensional models of $\mathrm{CP}$ using CFA. The three-dimensional model of $\mathrm{CP}$ includes interpersonal citizenship behaviors, organizationally directed citizenship behaviors, and conscientious initiative (Coleman \& Borman, 2000). The two-dimensional model includes OCB-I (i.e., interpersonal citizenship) and OCB-O (i.e., organizationally directed citizenship and conscientious initiative). In the one-dimensional model, we let all 15 items to load on one general dimension. We combined 
the second and third study samples to run these analyses. All analyses were conducted with Lisrel 8.54 (Jöreskog \& Sörbom, 2003) using a covariance matrix.

\section{Results}

We first compared the three-dimensional, twodimensional, and one-dimensional models of CP with Lisrel 8.54 (Jöreskog ve Sörbom, 2003). Results of these analyses revealed that compared to one- and two-factor models, the three-factor model exhibited better fit to the data $(\chi 2(90)=388.6, p<0.001$, CFI $=.97$, TLI $=.97$, RMSEA $=.068)$. In addition, AIC and ECVI values of the three-factor model were lower than the two alternatives, indicating better fit.

Next, we ran a CFA with all variables measured in Study 3. Results of the CFA showed that all path coefficients were significant $(p<.05)$ and the model produced a good fit $\left(\chi^{2}(8, \mathrm{~N}=813)=17.641, p=.00, \chi^{2} /\right.$ $\mathrm{df}=2.00, \mathrm{CFI}=.96, \mathrm{TLI}=.96, \mathrm{NFI}=.92, \mathrm{RMSEA}=.044$ $[90 \% \mathrm{CI}=.043-.045], \mathrm{SRMR}=.054)$. Next, we tested the proposed relationships between the antecedents and CP dimensions. All items significantly loaded on the relevant latent construct and the model produced a good fit $\left(\chi^{2}(3, \mathrm{~N}\right.$ $=514)=8.30, p=.00, \chi 2 / \mathrm{df}=2.36, \mathrm{CFI}=.96, \mathrm{TLI}=.95$, $\mathrm{NFI}=.92$, RMSEA $=.050$ [90\%CI $=.049-.052]$, SRMR $=.057)$. When we examined specific hypotheses, the path coefficients between satisfaction with co-workers and ICP, and procedural justice and OCP were not significant. ICP was significantly predicted by agreeableness $(\beta=$ $.33, p<.01)$ and group cohesiveness $(\beta=.21, p<.01)$. OCP was significantly predicted by satisfaction with supervisor $(\beta=.15, p<.01)$, affective commitment $(\beta$ $=.32, p<.01)$, and normative commitment $(\beta=.30, p<$ $.01)$. Conscientious initiative was significantly predicted by satisfaction with nature of work $(\beta=.17, p<.01)$, job involvement $(\beta=.25, p<.01)$, and conscientiousness $(\beta=.25, p<.01)$. Therefore, most of the hypothesized relationships were supported.

\section{General Discussion}

The aim of the current study was to examine the construct validity of CP in Turkey, using both qualitative and quantitative approaches. We investigated the face, content, factorial, and discriminant validity, and the reliability of CP. Results of the current study supported that the three-dimensional model of CP is both reliable and valid in the Turkish context. Furthermore, results showed that the three-dimensional model is better than the other conceptualizations. Contrary to LePine et al. (2002) and Hoffman et al. (2007), our data showed that the three-dimensional model fits the data better than the latent model. Our findings, in general, demonstrate that employees distinguish among their jobs, co-workers, and the organization successfully, and the reciprocity between the employee and these beneficiaries can be explained based on the target similarity and social exchange perspectives.

Finally, we reviewed the meta-analyses on CP and developed a model of predictors using the target similarity, social exchange, and intrinsic motivation theoretical frameworks. Using the target similarity framework, we chose most of the predictors from previous meta-analyses of CP (e.g., LePine et al., 2002; Organ, 1995; Podsakoff et al., 2000, 2009). However, we also investigated the predictive effects of group cohesion and job involvement, which received relatively little attention from scholars. In addition to finding support for a target similarity effect based on the beneficiary of the $\mathrm{CP}$, our study incorporated social exchange, personality, and indirectly intrinsic motivation frameworks. Social exchange theory states that employees consistently evaluate their relationships with their co-workers, organizations, and jobs. Therefore, the relationships of job satisfaction, organizational commitment, and group cohesion with CP dimensions were as expected and consistent with the literature. The well-formed relationship between some personality variables and $\mathrm{CP}$ dimensions were also reported in the current study. Although conscientiousness was the best personality predictor of both task performance and $\mathrm{CP}$, we believe it predicts extra effort to do one's job in a more effective and efficient way, namely job/task initiative. Therefore, the current study extends previous literature by examining conscientiousness as a specific predictor of conscientious initiative.

Most of our hypotheses were supported by the data and showed that CP categorized by the beneficiary of the specific behaviors might have different predictors. However, the hypothesized relationships between satisfaction with co-workers and ICP, and procedural justice with OCP were not significant. We should note that the correlation among these two sets of constructs were significant $(r=.20$, and $r=.33, p<.01$, respectively). It looks like the existence of other variables explained more variance, and the path coefficients became nonsignificant for these constructs. However, it is very important to test some important predictors together in order to better understand their relative importance.

Finally, as the current study is one of the rare studies investigating the three-dimensional CP model, the literature would benefit from replications or extensions in different organizational and cultural settings. The three-dimensional CP model demonstrates substantial potential for use in both research and applied settings. We hope our research contributes to the rich citizenship literature and facilitates cross-national studies. 